
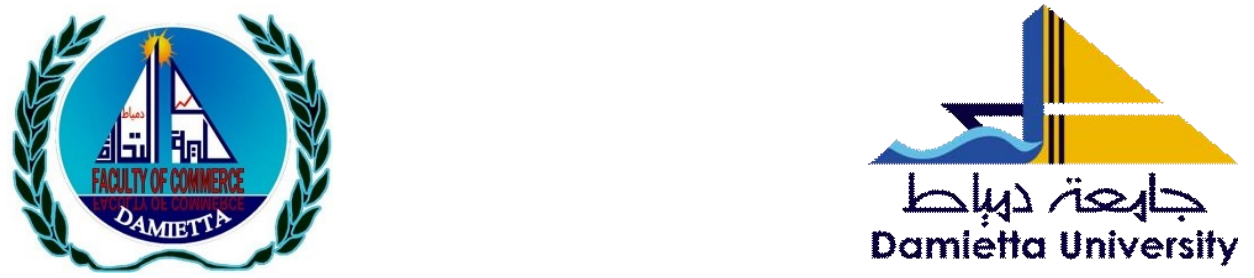

The Effect of Quality and Timeliness of Limited Review Report on Perceived Interim Financial Reporting Quality during COVID-19 Pandemic Crisis: Evidence from Egypt

By

Hebatallah Abd EI Salam Badawy

Assistant Professor of Accounting and Auditing

Faculty of Commerce - Alexandria University

Associate Professor of Accounting and Auditing

Faculty of International Business and Humanities (FIBH) - Egypt Japan

University of Science and Technology (E-JUST)

Heba782001@yahoo.com

Heba.badawy@ejust.edu.eg

Scientific Journal for Financial and Commercial Studies and Researches (SJFCSR)

Faculty of Commerce - Damietta University

Vol.2, No.2, Part 1., July 2021

\title{
APA Citation:
}

Badawy, H. A. (2021). The Effect of Quality and Timeliness of Limited Review Report on Perceived Interim Financial Reporting Quality during COVID-19 Pandemic Crisis: Evidence from Egypt, Scientific Journal for Financial and Commercial Studies and Research, Faculty of Commerce, Damietta University, 2(2)1, pp.25-74.

Website: https://cfdj.journals.ekb.eg/ 


\begin{abstract}
In order for financial information to be used by investors to take informed decisions, it should be characterized by its relevance and faithful representation. In times of crisis, investors' demand and reliance on financial information will be higher in order to reduce the level of uncertainty and information asymmetry and increase their confidence in management's performance. The objective of this study is to investigate and analyze the impact of quality of limited review reports, measured by adding a key audit matters paragraph (KAM hereafter) related to COVID19 pandemic to the limited review report and its timeliness, measured by the limited review report lag, on the perceived quality of interim financial reports issued at the end of the third quarter of 2020.

Based on a sample of 95 firms listed on the Egyptian stock exchange (EGX hereafter), the researcher found that the timeliness of limited review reports is positively and significantly associated with the perceived quality of financial reporting from the investors' point of view. Investors appreciate and value the timeliness of financial reports and the limited review report during COVID-19 pandemic crisis time. Concerning the impact of the quality of limited review report, the researcher didn't find evidence regarding the informational value of KAM paragraph and its effect on the perceived quality of interim financial reports. This might be because adding KAM paragraph on COVID-19 pandemic is not firm specific and at the same time, not presenting additional information to investors other than that available in the interim financial reports.
\end{abstract}

Keywords: Limited review report quality, Interim financial reports, Limited review report lag, COVID-19 pandemic, Egypt. 


\section{Introduction}

Financial information is considered an important resource for any market participant. It is not useful for its users only, but also for the society as a whole, as it helps in resource allocation decisions, which in turn have a great impact on the society (Tasios \& Bekiaris, 2012). Generally speaking, investors need relevant and reliable financial information to take informed and rational investment decisions. According to the agency theory, firms issue their financial reports to help in reducing information asymmetry between managers, creditors, investors and other stakeholders (Lin et al., 2014; Martínez-Ferrero, 2014).

In order for financial information to be a useful input to the decision-making process, it should be both relevant and provides a faithful representation of what is supposed to represent (IAASB, 2018). Financial information is relevant when it affects its users' decisions and is offered on a timely basis (Bae \& Woo, 2015) before it becomes irrelevant (Jonas $\&$ Blanchet, 2000). Also, financial information should be reviewed by an independent auditor in order to be credible and reliable. The information asymmetry between the users and providers of financial statements creates the demand for high quality audit (Abdollahi et al., 2020), which is necessary for a well-functioning capital market (Skinner \& Srinivasan, 2012) and enhances the allocation of resources (Dye, 1993) and the reliability of financial statements from the investors' point of view (Chen et al., 2014)

Interim financial reports represent an important source of information for decision makers in general and investors in particular. According to Al-Shatnawi (2017), the financial information included in such reports helps decision makers to have updated information on the company's performance and financial position and accordingly they could assess their decisions taken before instead of waiting for the annual financial statements. In addition to the content of interim financial reports, the issuance of such reports in the right time is very important and will increase the benefits and usefulness of financial information to its users. 
In the time of crisis, users of financial reports demand high quality financial information more than ever before, as they are suspicious that managers are hiding poor performance and that's why their demand for reliable financial information increases. COVID-19 pandemic crisis is the most important event that took place since the financial crisis in 2008, although it is hitting many industries harder than that during the financial crisis in 2008. COVID-19 pandemic has its drastic and severe economic implications which make investors and stakeholders need high quality information more than ever before and companies need to review all accounts that require estimates and judgement (Gould \& Arnold, 2020). As a consequence, providing meaningful and timely disclosures related to the effects of the pandemic is important to stakeholders (Joshi, 2020). According to the IAS34 "Interim Financial Statements", the entity should disclose the events and transactions that have a significant effect on its financial position and performance and accordingly the entities should provide additional disclosure related to the effect of COVID-19 pandemic crisis (PwC, 2020).

It is expected that COVID-19 pandemic has its severe and unprecedented effects and company management, accountants and auditors will discuss the financial effects of COVID-19 pandemic on the liquidity, financial position and financial performance of the companies. By the end of 2020, it is expected that companies will address the financial effects of the pandemic in their annual and interim financial reports (Joshi, 2020; PwC, 2020). In addition, COVID-19 pandemic will have its impact on the auditor's work and the way of collecting evidence and this represent a challenge to auditors as well.

The objective of this study is to examine and analyze the effect of quality of limited review report, measured by adding a KAM paragraph related to COVID-19 pandemic crisis in the limited review report issued at the end of the third quarter of 2020 and its timeliness, measured by the limited review report lag (LRRL) on the perceived quality of interim financial reporting from the investors' point of view, measured by the market value of the firms included in the sample after issuing the limited review report. 
The importance and motives of this study stem from the importance of the output of review process for the decision-making process, as the value of audit report in general and the limited review report in particular is questionable and is part of the audit expectation gap (AlThuneibat et al., 2008). Also, the importance of the study is derived from the relationship being examined, which is the effect of quality and timeliness of limited review report on the perceived financial reporting quality in a very critical time, which is during COVID-19 pandemic crisis, especially that financial reporting quality and audit quality in general are interrelated and are affected collectively by the economic situation and conditions (Gaynor et al., 2016).

Also, according to Abdollahi et al. (2020), there is scarcity in the number of research papers that were conducted in the area of limited review quality, value relevance of limited review reports and audit firm size in general and how they affect the value relevance of accounting and financial information. Accordingly, the importance of this study results from discussing one of the most important topics that is still underexamined, which is the quality and timeliness of limited review report and its value relevance; how they are reflected in the stock price. It is important to mention that the current study is different from that of Robu \& Robu (2015), which investigated how the effect of accounting information on stock return might be affected by audit opinion and affiliation to one of the Big4 on the investment decisions. The current study investigated how the value relevance of accounting information (net income and book value of equity) might be affected by adding a KAM paragraph related to COVID-19 pandemic in the limited review report. Also, Abdollahi et al. (2020) noted that limited attention was given to the value relevance of audit opinion and audit firm size and accordingly the researcher investigated the impact of adding a KAM paragraph on COVID-19 pandemic in the limited review report and timeliness of such report on the market value of firms listed on the EGX and in the additional analysis, the researcher investigated how the effect of accounting information on the market value of the firms might be moderated by the quality of limited review report, as measured by the inclusion of a KAM paragraph on COVID-19 pandemic. 
Therefore, this study is highly important to auditors and users of financial reports in general and investors in particular, as it is expected to shed the light on the role of limited review report and its value to investors, especially in the time of crisis and provide evidence regarding whether the recent modifications in the audit report has fulfilled its expected role and reduced the audit expectation gap. Finally, Egypt is considered a low litigation and investor protection economy and studying audit quality in general and quality of limited reviews in particular in this type of economy is of paramount importance (Skinner \& Srinivasan, 2012).

The rest of the paper will be organized as follows: Section 2 reviews the relevant literature related to quality and timeliness of limited review report and interim financial reporting quality and develop the research hypotheses. Section 3 presents the research design, methodology and measurement of research variables. Section 4 discusses the empirical results. Section 5 presents the conclusions, recommendations and implications for future research.

\section{Literature Review and Hypotheses Development}

\subsection{Interim Financial Reporting Quality}

Financial information offered by firms is considered an important source of information for any market participant. As resources are limited, financial information is not considered useful for its users only, but also for the society as a whole (Tasios \& Bekiaris, 2012). In order for information to be useful, it should be both relevant and provides a faithful representation of what is supposed to represent (IAASB, 2018). For information to be relevant, it should make significant change in its users' decisions and offered to them on a timely basis (Bae \& Woo, 2015) before it becomes irrelevant (Jonas \& Blanchet, 2000). In general, investors need such information in order to evaluate their investment decisions taken before and to take decisions regarding their investment in securities. According to agency theory, financial information helps in reducing information asymmetry between managers, creditors, investors and other stakeholders (Lin et al., 2014; Martínez-Ferrero, 2014). It is important that the information presented by firms on their financial position and operations to be of a higher quality, as according to the signaling theory, high quality accounting information may be a signal of firms' good performance and managers are more encouraged to offer high quality accounting information in order to avoid adverse selection (Lin et al., 2014). 
Jonas \& Blanchet (2000, p. 357) defined quality of financial reporting as "full and transparent financial information that is not designed to obfuscate or mislead users". Reliable financial statements improve investors' and creditors' ability to assess the financial position and liquidity of the entity (Lightstone et al., 2012). However, more frequent financial reports will allow investors and creditors to update their assessment.

Financial reporting quality can be measured by earnings quality using Jones model or modified Jones model (Lin et al., 2014) and by its value relevance. From the investors' point of view, net income and book value of equity are highly important in their investment decisions. Investors tend to compare the book value of equity with the market value of equity in order to make rational investment decisions. As a consequence, it is expected that positive information will increase the value of firm's outstanding shares (Akeem et al., 2020).

Interim financial reports are those reports that are issued by companies and include a complete or a condensed set of the company's financial statements for a period less than a year; a month, quarter of semiannual (ICAEW, 2020). According to IAS34 "Interim Financial Statements", the firm should disclose the events and transactions that have a significant effect on its financial position and performance. The purpose of issuing interim financial reports is to update external parties of any new events or activities since the last annual report and not to duplicate information (ICAEW, 2020). Interim financial reports represent an important source of information for decision makers in general and investors in particular. The information included in such reports helps decision makers to have updated information on the company's performance and financial position and accordingly they could assess their investment decisions taken before instead of waiting for the annual financial statements (Al-Shatnawi, 2017).

It is important that interim financial reports are of a higher quality for its users. Based on a survey of 72 investment specialists in Jordan, AlShatnawi (2017) found evidence that the qualitative characteristics of accounting information whether primary or enhancing characteristics included in the interim financial reports affect their quality, which is of great importance to decision makers. 
Based on the discussion above, it can be noted that financial reports in general and interim financial reports in particular are of paramount importance to its users in general and investors in particular. Investors need more frequent financial reports in order to assess their prior investment decisions and take future ones. During COVID-19 pandemic, it is expected that investors will demand reliable financial reports more than ever before and accordingly firms should provide additional disclosure related to the effect of COVID19 pandemic crisis ( $\mathrm{PwC}, 2020)$.

\subsection{Limited Review Report Quality and Interim Financial Reporting Quality}

DeAngelo (1981, p. 186) defined audit quality as "the probability that a given auditor will both (a) discover a breach in the client's accounting system, and (b) report the breach". According to this definition, audit quality doesn't depend on the auditor's ability to discover material misstatements in the financial statements only, but also on the auditor's communication of these misstatements in his report. As audit quality can't be observed, the audit report, which is the output of the audit process and a means of communication between the auditor and users of financial reports, may be considered as an information tool (Velte \& Issa, 2019) and is used by stakeholders when they assess the level of audit quality.

The audit report is being extensively investigated by many researchers (for example: Al-Thuneibat et al., 2008; Robu \& Robu, 2015) because of its importance and its impact on stakeholders' decisions in general and investors' decisions in particular. Robu \& Robu (2015) investigated the effect of auditors' report content, in the form of audit opinion and affiliation to one of the Big4 audit firms on investors' decisions, as measured by stock return. Based on a sample of 59 companies listed on Bucharest Stock Exchange during 2012, the authors found evidence that audit opinion and affiliation to one of the Big4 audit firms are significantly valued by investors, as evidenced by stock return and that accounting information affects stock return depending on the type of audit opinion and size of audit firm. 
Also, investors value the audit report as a way to enhance the quality of financial reporting (Okolie \& Izedonmi, 2014). Abdollahi et al. (2020) noted that audit reports are value relevant, as the information content of auditors' reports will affect the investors' estimation of future cash flows and their fluctuation, ability of the firm to continue its activities. It is expected that audit opinion will affect investors' decisions regarding their valuation of stock prices (Robu \& Robu, 2015). In addition, Kaplan et al. (2020) investigated the impact of the type and disclosures of audit reports on information uncertainty. Based on a sample of 450 financially distressed IPO firms in USA during the period 2002-2017, the authors found evidence that hybrid audit reports and going concern audit opinion will result in a significant decrease in information uncertainty (Kaplan et al., 2020).

Standardized audit reports were being criticized for their standard format and wordings and low level of transparency and disclosure. Because audit reports are highly valued by the company's stakeholders in general and investors in particular, those stakeholders demand more information that is relevant and will help them in making informed decisions. As a result of stakeholders' demand for more informative and relevant audit reports and because of the information gap which exists between what the users of financial reports demand and what auditors provide in their audit report, standard setters and regulators (IAAS, PCAOB, FRC and EC) have taken serious steps towards enhancing the informativeness of audit reports by adding KAM paragraph (by the IAASB) or CAM (by the PCAOB) to the auditors' reports (Gold \& Heilmann, 2019; Zeng et al., 2020). According to ISA701, KAM are those matters that, according to the auditors' professional judgement, are considered of great significance in auditing the financial statements in the current period (IFAC, 2015). 
Auditors add a CAM or KAM paragraph to their audit report to add value and communicate some audit insights to investors regarding audit difficulties and accordingly it is expected that the information gap between users and providers of the financial statements will be reduced. KAM paragraph is concise and straight forward and it is expected that it will draw the attention of investors and other stakeholders more than the disclosures in the financial statement footnotes, as this paragraph is presented by an independent auditor (Christensen et al., 2014). Expanded audit reports (after adding KAM paragraph) are expected to affect investors' behavior significantly (Sutthipan, 2020) and will increase investors' willingness to pay and buy the firms' shares when they disclose information about the firms' higher financial reporting quality (Elliott et al., 2020).

Prior research investigated the impact of adding KAM (CAM) paragraph to auditors' reports on investors' decisions, however, results were inconclusive. On one side, Christensen et al. (2014) found that investors tend to change their investment decision after receiving an audit report that includes a CAM paragraph. Based on a sample of 1,125 firmyear observations of firms listed on the Italian Stock Exchange during the financial distress period from 2007 - 2010, Ianniello \& Galloppo (2015) found that audit opinion with matter of emphasis on going concern or financial distress has a positive impact on the stock prices of firms, while qualifications in the audit report have a negative impact on stock prices. This indicates that the audit report has an information content for investment decisions. Consistently, Gold et al. (2020) investigated the impact of KAM on financial reporting behavior in the form of managers' opportunistic and aggressive reporting behavior. The authors noted that KAM increases the level of financial reporting transparency and that managers feel that they are scrutinized and are under pressure, and this reduces aggressive reporting and increases the level of financial reporting quality. Also, the authors added that the impact of KAM on managers' reporting behavior differs according to whether the KAM is firm specific or non-firm specific and that non-firm specific KAM attract less investor attention and don't add information value in comparison with firm specific KAM, as standardized wording in KAM doesn't require a lot of time or effort to process and evaluate. 
On the other hand, Bédard et al. (2014) didn't find significant evidence regarding the information content of KAM paragraphs; its effect on the investor is low. Also, the authors didn't find significant effect of adding such paragraphs on the audit quality, cost or efficiency. Consistently, Lennox et al. (2016) didn't find significant effect of adding KAM paragraph related to the risk of material misstatements on market reaction, as investors are already informed of these risks before by the management before the auditor discloses them in his report. In addition, $\mathrm{Li}$ (2017) investigated the effect of introducing KAM in auditor reports on market reaction and audit quality in China. Based on a sample of $84 \mathrm{~A}+\mathrm{H}-$ share listed firms in 2016, the author didn't confirm the information content of KAM and didn't find significant effect of introducing KAM on market reaction nor audit quality. The author noted that disclosing KAM in the auditor's report doesn't have significant effect on the quality of financial reporting. Also, Bédard et al. (2019) didn't find significant effect of the first-time implementation of expanded audit reports nor subsequent years implementation on investors nor audit quality, auditor fees or audit report lag.

In a recent study, Köhler et al. (2020) conducted an experiment to examine the effect of KAM related to good will impairment on the communicative value of the auditors' report. Based on a sample 89 professional investors from US, Germany, UK and other countries and 69 non-professional investors, the authors found that there is no communicative value of KAM paragraphs for non-professional investors indicating that such investors might have difficulty in interpreting the information in these paragraphs. However, for professional investors, the authors found that in case of negative KAM, investors value the information included in these paragraphs and their trust in the audit and the financial statements is enhanced and their assessment of the economic situation is better, as negative information draws investors' attention to issues that they have not been aware of before. On the other side, positive KAM is ill-perceived, and investors view such paragraphs as a way of appeasement. On the other side and based on a sample of 381 firm year observations of non-financial firms registered on Thailand Stock Exchange during the period from 2016 - 2018, Sutthipan (2020) found negative and significant association between the level of KAM reporting (as measured by the number of words) and the share price of these firms. 
Based on the analysis of prior literature, it can be noted that the impact of KAM paragraph on share prices was intensively investigated in prior literature, however results were mixed. One stream of research papers found evidence that a KAM paragraph has a communicative and information value, and it was added to reduce information asymmetry level between users and providers of financial reports on one side and the audit expectation gap on the other side. The other stream of research papers found that KAM doesn't have any added value from the investors' point of view. The researcher thinks that the mixed and inconclusive prior research findings and conclusions might stem from the content of KAM paragraph and the background and knowledge of investors.

As high audit quality and high disclosure quality help in regaining investors' confidence and their perception of financial reporting quality (Alwardat, 2019), reviewing interim financial reports is crucial for decision makers in general and investors in particular and will help in reducing information asymmetry and having more accurate and reliable accounting information (Sulaiman \& Ahmad, 2016). Reviewing quarterly reports are conducted in order to improve the relevance and reliability of reported earnings (Manry et al., 2003). It is important to note that limited review is different from annual audit, as auditors in the annual audit provide positive reasonable assurance that the financial statements are fairly stated and free from material misstatements. On the other hand, auditors in the limited review provides negative reasonable assurance that they are not aware of any material modifications in the financial statements and the review is considered to be less rigorous than the annual audit (Krishnan \& Zhang, 2005; ICAEW, 2020)

Limited research was conducted on the quality of limited review reports or the quality of audit reports other than that issued on the annual financial reports. In USA, Manry et al. (2003) examined the impact of timely reviews of quarterly reports on the relevance and reliability of reported earnings. Based on a sample of 1,121 firm-year observations during the period from 1990-1995, the authors found that when auditors make timely reviews of interim earnings, the relationship between 
earnings and returns is contemporaneous, which means that prices responded quickly when earnings are reviewed on a timely basis than when reviewed retrospectively. In China, Chen et al. (2014) investigated the effect of semi-annual audit reports on investors' reaction. Based on a sample of 2,326 firm-year observations of Chinese firms, the authors found evidence that semi-annual audits reduce variations in investors' assessment of firm value in the form of stock returns and trading volume.

In times of crisis, users of financial reports demand high quality financial information more than ever before, as they are suspicious that managers are hiding poor performance and that's why their demand for reliable financial information increases. Lin et al. (2014) asserts that high quality financial reporting is very important to investors, especially during the periods of financial crisis or distress, as such information helps in reducing information asymmetry, information risk and market illiquidity and increasing investors' confidence, and at the same time, it allows them to be informed of the firm's business decisions and reduces the management's discretion to expropriate the wealth of outside investors and creditors.

COVID-19 pandemic crisis is the most important event that took place since the financial crisis in 2008, although it is more severe in its impact on different sectors and industries. Kegalj (2020) discussed the key areas that need to be considered when the entities prepare their interim financial statements, as a result of COVID-19 pandemic effects. Those key areas are 1- Going concern: management needs to assess the appropriateness of preparing their financial statements on a going concern basis (Joshi, 2020) and if there is a material uncertainty related to the company's ability to continue as a going concern, this information should be disclosed in the interim financial reports. 2- Impairment of financial and non-financial assets, if the company tested its financial and non-financial assets and found evidence of impairment loss, they should disclose this in their interim financial statements. 3- Property, plant and equipment, the entity may need to reassess its estimates of the useful lives and residual values of its long-term assets as a result of the current conditions. 4- Fair value measurement, as a result of the effect of COVID-19 pandemic, 
companies may need to reevaluate the fair values of their assets. 5Inventories, as a result of the current circumstances, companies may need to update their estimates of their net realizable values and test for any write downs.

It is expected that COVID-19 pandemic will have its significant impact on accountants who prepare the companies' financial statements, as well as the auditors who review such statements (Joshi, 2020). COVID19 pandemic will have its severe effects on the audit process. It may lead to difficulty in applying some audit procedures and reaching sufficient appropriate audit evidence which is necessary to form a reasonable base for the audit opinion (IAASB, 2020). According to the IAS701 "Communicating Key Audit Matters in the Independent Auditor's Report", auditors will discuss the key audit matter which is the impact of COVID-19 pandemic on the financial position and performance of the entity and refer to a related disclosure in the financial statement (if any) and how the entity addresses such impact (IAASB, 2020).

In Egypt, auditors mentioned in the KAM paragraph that COVID19 pandemic has its severe effects on the financial performance of the companies and that management has taken effective steps to combat the effect of this pandemic, however the effect on the operations of the company depends upon the duration of this crisis which is difficult to estimate in the current time. Adding a KAM paragraph to the limited review reports is expected to increase the level of disclosure and transparency related to COVID-19 pandemic. It is expected that the quality of limited review report, measured by adding a KAM paragraph on COVID-19 pandemic in the limited review report will provide informational value to investors and increase their confidence in the financial information reported by the Egyptian firms in their interim reports and the related limited review process.

Accordingly, the first research hypothesis can be developed as follows:

H1: Limited review report quality is positively and significantly associated with interim financial reporting quality of listed companies during COVID-19 crisis in Egypt 
Dr. Hebatallah Badawy

\subsection{Limited Review Report Timeliness and Interim Financial Reporting Quality}

As mentioned in the discussion above, for information to be relevant, it should be available to its users in general and investors in particular in the right time and before it becomes irrelevant in order to make informed decisions. Delays in financial reporting have a negative impact on the market values of the firms and will raise suspicions among market participants that the company might be facing problems or hiding bad news. Since financial statements can't be shared except when they are audited, audit report lag will lead to the delay of issuing the firms' financial reports (Akeem et al., 2020).

Prior research focused on the determinants of audit report lag, such as audit firm size, firm characteristics and corporate governance attributes, and the impact of audit report lag on stakeholders' behavior and decisions. For instance, Bae \& Woo (2015) investigated the impact of audit report lag on analysts' forecast error. The authors noted that in order for financial information to be relevant, they should be offered on a timely basis and there should be an equilibrium between relevance and reliability. Based on a sample of 989 firm-year observations from firms listed on the Korean Exchange during the period from 2004-2010, the authors found positive and significant association between audit report lag and analysts' forecast errors. Also, Gligorić et al. (2019) investigated the impact of market capitalization on audit report lag (ARL). The authors noted that the delay between the issuance of financial reports and the delivery of audit report will affect the value of information used by investors to evaluate their investments. Based on a sample of 400 financial reports from Belgrade Stock Exchange in 2017, the authors found a negative and significant correlation between ARL on one side and market capitalization on the other side. Timeliness of audit reports is a way of reducing information asymmetry by improving share prices and reducing insider trading and rumors around the firm's financial health and performance (Fakhfakh Sakka \& Jarboui, 2016). 
Additionally, prior research investigated the impact of audit report lag on investors' decisions, however there is scarcity in prior literature focusing on the impact of timeliness of limited review reports on investors' decisions and the quality of financial reports from the investors' point of view, especially during crisis times, when investors' demand of highquality financial information is high.

It is expected that COVID-19 pandemic crisis will affect the extent of auditors' work and that more rigorous audits should be conducted (ICAEW, 2020). In general, auditors rely in their review of interim financial reports on management inquiries and analytical procedures to provide negative reasonable assurance that nothing has come to their attention that causes them to believe that the interim financial reports are not presented fairly, in all material respect, in accordance with the applicable financial reporting framework. However, due to COVID-19 crisis and its effect on the company's business operations and financial performance, auditors are expected to perform more rigorous audit procedures, especially in their assessment of the going concern assumption and management's estimates in the interim financial reports of 2020 (ICAEW, 2020). On the other hand, investors will ask for more frequent financial reports, that will be credible and valuable when reviewed by independent auditors.

Based on the discussion above, it is clear that the timeliness of the audit report in general and the limited review report in particular is of paramount importance to investors' decisions in general and in the time of crisis in particular. Investors need high quality financial information that is reliable and audited by independent auditors in order to be updated and revisit their prior expectations and take informed investment decisions. During COVID-19 crisis, investors will be suspicious if firms delay their reviewed interim financial reports and they need the high quality and reliable information more frequently and as soon as possible. 
Scientific Journal for Financial and Commercial Studies and Researches

Vol.2, No.2, Part 1., July 2021

Dr. Hebatallah Badawy

As a result, the researcher expects that investors will value timely limited review reports, and this will be reflected positively on the quality of the financial reporting from their point of view.

Accordingly, the second research hypothesis can be developed as follows:

H2: Limited review report timeliness is positively and significantly associated with financial reporting quality of listed companies during COVID-19 crisis in Egypt

Research Model

Independent variables

Dependent variable

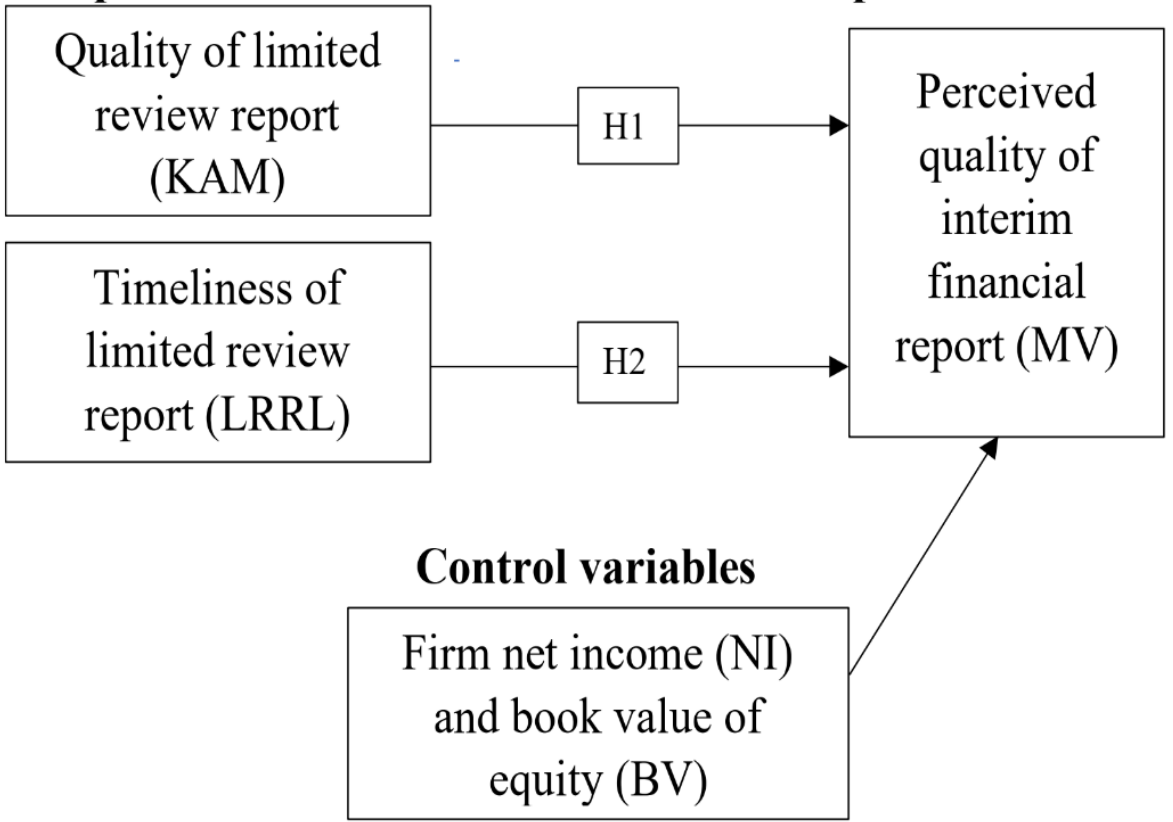




\section{Research Design and Methodology}

In this section, the researcher will present the research methodology, sample selection procedures, measurement of independent, dependent, and control variables used in the study and the derivation of multiple regression models.

\subsection{Sample and Data}

This study focuses on non-financial firms listed on the EGX at the end of the third quarter of 2020. The researcher chose this period to conduct the study because the announcement of COVID-19 pandemic was in January 2020 and the national lockdown was in March 2020. Accordingly, at the end of the third quarter, the impact of limited review report and its timeliness on the perceived quality of interim financial reporting can be analyzed.

The researcher excluded the financial firms and banks from the study because of their different nature and regulations. To reach the final sample, the researcher started with the total number of non-financial firms listed on the EGX which are 180 and to ensure consistency, the researcher excluded the firms that issue their financial statements at a date other than $31^{\text {st }}$ of December (38 firms). After excluding the firms with insufficient data (47 firms), the researcher reached a final sample of 95 non-financial firms (Table 1). Table (2) presents the distribution of the final sample across sectors.

Table (1) Sample selection procedure

\begin{tabular}{|l|c|}
\hline Total firms listed on the EGX & 220 \\
\hline Less: Firms in the financial industry & $(40)$ \\
\hline $\begin{array}{l}\text { Less: Firms that don't issue their financial statement on } \\
\text { December 31 }\end{array}$ & $(38)$ \\
\hline Less: Firms with insufficient data & $(47)$ \\
\hline Total number of firms in the final sample & $\mathbf{9 5}$ \\
\hline
\end{tabular}


Scientific Journal for Financial and Commercial Studies and Researches

Vol.2, No.2, Part 1., July 2021

Dr. Hebatallah Badawy

Table (2) Sample distribution across sectors

\begin{tabular}{|l|c|c|c|c|}
\hline & Frequency & Percent & $\begin{array}{c}\text { Valid } \\
\text { percent }\end{array}$ & $\begin{array}{c}\text { Cumulative } \\
\text { percent }\end{array}$ \\
\hline Basic Resources & 5 & 5.3 & 5.3 & 5.3 \\
\hline Chemicals & 6 & 6.3 & 6.3 & 11.6 \\
\hline Construction and Materials & 15 & 15.8 & 15.8 & 27.4 \\
\hline Food and Beverages & 15 & 15.8 & 15.8 & 43.2 \\
\hline Health Care \& Pharmaceuticals & 8 & 8.4 & 8.4 & 51.6 \\
\hline Industrial Goods, Services and Automobiles & 5 & 5.3 & 5.3 & 56.8 \\
\hline Media & 1 & 1.1 & 1.1 & 57.9 \\
\hline Oil and gas & 1 & 1.1 & 1.1 & 58.9 \\
\hline Personal and Household Products & 3 & 3.2 & 3.2 & 62.1 \\
\hline Real Estate & 21 & 22.1 & 22.1 & 84.2 \\
\hline Retail & 1 & 1.1 & 1.1 & 85.3 \\
\hline Telecommunications & 2 & 2.1 & 2.1 & 87.4 \\
\hline Travel \& Leisure & 11 & 11.6 & 11.6 & 98.9 \\
\hline Utilities & 1 & 1.1 & 1.1 & 100.0 \\
\hline Total & $\mathbf{9 5}$ & $\mathbf{1 0 0 . 0}$ & $\mathbf{1 0 0 . 0}$ & \\
\hline
\end{tabular}

3.2 Measurement of Variables

\subsubsection{Dependent variable: Perceived interim financial reporting quality}

$M V$ : Perceived interim financial reporting quality of the firm $(i)$ at the end of the third quarter of 2020 is measured by the firm's market value of equity which is the firm's share price after issuing the limited review report multiplied by the number of outstanding shares at the end of the third quarter of 2020. Consistent with Al-Thuneibat et al. (2008) that noted that the effect of audit report on investment decisions can be shown through its effect on share prices, the researcher will measure the perceived quality of interim financial reports from the investors' point of view through the market value of firms. 


\subsubsection{Independent variables: Limited review report quality and timeliness}

KAM: Limited review report quality is measured by the inclusion of a KAM paragraph on COVID-19 effect in the limited review report issued on the first 3 quarters of year 2020 (a dummy variable that takes the value (1) in case COVID-19 KAM paragraph is present in the limited review report and (0) otherwise). Consistent with Chui et al. (2020), the researcher used modified report issued by the independent auditor as a proxy for the quality of limited review report. Additionally, the researcher measured the quality of the limited review report by its value relevance, whether it is reflected in the share price and the market values of the firms or not, as the main focus of the paper is to investigate its impact on perceived financial reporting quality from the investors' point of view.

LRRL: Timeliness of limited review report is measured by limited review report lag using the natural logarithm of the number of days that elapse between the issuance of the interim financial report on the $30^{\text {th }}$ of September 2020 and the limited review report date (consistent with the measurement of Akeem et al., 2020 of audit report lag).

\subsubsection{Control variables:}

Following prior research (Ohlson, 1995; Chandrapala, 2013), the researcher included two main control variables that were proven to be value relevant and have positive and significant effect on the firm's market values (mainly from the investors' point of view). These variables are the firm's net income after tax $(N I)$ and the book value of equity $(B V)$.

$N I$ : Net income after tax of the firm (i) for the first three quarters in 2020. $B V$ : Book value of equity of the firm (i) at the end of the third quarter of 2020. 
Scientific Journal for Financial and Commercial Studies and Researches

Vol.2, No.2, Part 1., July 2021

Dr. Hebatallah Badawy

\subsection{Models Specification}

To test the effect of quality and timeliness of limited review reports on the perceived quality of interim financial reporting, the researcher developed the following multiple regression models:

Model 1: The effect of limited review report quality (KAM) on the perceived quality of interim financial reporting (MV)

$$
M V_{i t}=\beta_{0}+\beta_{1} N I_{i t}+\beta_{2} B V_{i t}+\beta_{3} K A M_{i t}+\varepsilon_{i t}
$$

Model 2: The effect of limited review report timeliness (LRRL) on the perceived quality of interim financial reporting (MV)

$$
M V_{i t}=\beta_{0}+\beta_{1} N I_{i t}+\beta_{2} B V_{i t}+\beta_{3} L R R L_{i t}+\varepsilon_{i t}
$$

Model 3: The effect of KAM and LRRL on MV (The basic model)

$$
M V_{i t}=\beta_{0}+\beta_{1} N I_{i t}+\beta_{2} B V_{i t}+\beta_{3} K A M_{i t}+\beta_{4} L R R L_{i t}+\varepsilon_{i t}
$$

Model 4: The effect of KAM and LRRL after adding another audit quality measure to the basic model (The extended model)

$$
M V_{i t}=\beta_{0}+\beta_{1} N I_{i t}+\beta_{2} B V_{i t}+\beta_{3} K A M_{i t}+\beta_{4} L R R L_{i t}+\beta_{5} B I G 4_{i t}+\varepsilon_{i t}
$$

Model 5: Using KAM as a moderating variable in the basic model

$M V_{i t}=\beta_{0}+\beta_{1} N I_{i t}+\beta_{2} B V_{i t}+\beta_{3} K A M_{i t}+\beta_{4} K A M^{*} N I_{i t}+\beta_{5} K A M^{*} B V_{i t}+\varepsilon_{i t}$

Model 6: Using KAM as a moderating variable in the extended model

$$
\begin{gathered}
M V_{i t}=\beta_{0}+\beta_{1} N I_{i t}+\beta_{2} B V_{i t}+\beta_{3} K A M_{i t}+\beta_{4} K A M^{*} N I_{i t}+\beta_{5} K A M^{*} B V_{i t}+ \\
\beta_{6} L R R L_{i t}+\beta_{7} B I G 4_{i t}+\varepsilon_{i t}
\end{gathered}
$$




\section{Empirical Findings}

\subsection{Descriptive statistics}

Table (3) presents the descriptive statistics of the variables included in the study. It is clear from the table that the $M V$ of firms in the study ranges from 6 million to 21.4 billion Egyptian pounds with an average 1.3 billion Egyptian pounds. The $N I$ ranges from -421.4 million to 1.85 billion Egyptian pounds with an average 58.7 million Egyptian pounds. As for the $B V$, it ranges from 315 thousand to 31.4 billion Egyptian pounds with an average 1.4 billion Egyptian pounds. Also, table (3) shows that $27.37 \%$ of the firms in the sample received a modified limited review report with a $K A M$ paragraph on COVID-19 and that the minimum natural logarithm of the number of days that elapse between the interim financial report date and the limited review report date ranges from 3.04 to 3.87 with an average 3.73 . Finally, table (3) reveals that $14.74 \%$ of the interim reports of the 95 firms included in the study are reviewed by an audit firm affiliated to one of the $B I G 4$ audit firms.

Table (3) Descriptive Statistics

\begin{tabular}{|c|c|c|c|c|c|c|c|}
\hline $\begin{array}{c}\text { Vari } \\
\text { able }\end{array}$ & $\begin{array}{c}\text { Expected } \\
\text { sign }\end{array}$ & Mean & Median & $\begin{array}{c}\text { Standard } \\
\text { Deviation }\end{array}$ & Minimum & Maximum & N \\
\hline $\boldsymbol{M} \boldsymbol{V}$ & & $1,313,760,202$ & $420,000,000$ & $2,861,533,149$ & $6,000,000$ & $21,423,748,580$ & 95 \\
\hline $\boldsymbol{N I}$ & + & $58,707,400$ & $4,747,200$ & $230,032,945$ & $-421,411,534$ & $1,851,718,000$ & 95 \\
\hline $\boldsymbol{B} \boldsymbol{V}$ & + & $1,411,269,156$ & $277,687,405$ & $4,487,212,960$ & 315,365 & $31,399,260,241$ & 95 \\
\hline $\boldsymbol{K} \boldsymbol{A M}$ & + & 0.2737 & 0.0000 & 0.44821 & 0.00 & 1.00 & 95 \\
\hline $\boldsymbol{L} \boldsymbol{R} \boldsymbol{L}$ & - & 3.7347 & 3.7600 & 0.11138 & 3.04 & 3.87 & 95 \\
\hline $\boldsymbol{B I G} \boldsymbol{4}$ & + & 0.1474 & 0.0000 & 0.35635 & 0.00 & 1.00 & 95 \\
\hline
\end{tabular}

\subsection{Correlation analysis}

Table (4) depicts the correlation between the dependent, independent and control variables. Pearson correlation matrix in table (4) demonstrates that no correlation between the independent variables more than 0.7 , which indicates that the correlation between the variables is not a serious problem (Shrestha, 2020). 
Contrary to expectations, table (4) shows that $K A M$ is positively but insignificantly correlated with $M V$ and $L R R L$ is negatively and insignificantly correlated with $M V$. On the other side and as expected, $N I$, $B V$ and $B I G 4$ are positively and significantly associated with $M V$. Also, it will be clear from the regression results (shown in the next section) that multicollinearity problem doesn't exist, as VIF values are below 10 and Durbin Watson statistics are between 1.5 and 2.5, indicating no autocorrelation problem.

Table (4) Pearson correlation matrix $(\mathrm{N}=95)$

\begin{tabular}{|l|c|c|c|c|c|c|}
\hline Variable & $\boldsymbol{M} \boldsymbol{V}$ & $\boldsymbol{N I}$ & $\boldsymbol{B} \boldsymbol{K}$ & $\boldsymbol{K} \boldsymbol{A M}$ & $\boldsymbol{L R R L}$ & $\boldsymbol{B I G} 4$ \\
\hline $\boldsymbol{M} \boldsymbol{V}$ & 1 & & & & & \\
\hline $\boldsymbol{N I}$ & $0.808^{* * *}$ & 1 & & & & \\
& $(0.000)$ & & & & & \\
\hline $\boldsymbol{B} \boldsymbol{V}$ & $0.913^{* * *}$ & $0.657^{* * *}$ & 1 & & & \\
& $(0.000)$ & $(0.000)$ & & & & \\
\hline $\boldsymbol{K} \boldsymbol{A M}$ & 0.035 & 0.059 & 0.024 & 1 & & \\
& $(0.739)$ & $(0.571)$ & $(0.840)$ & & & \\
\hline $\boldsymbol{L R R L}$ & -0.107 & -0.072 & 0.041 & 0.140 & 1 & \\
& $(0.300)$ & $(0.486)$ & $(0.690)$ & $(0.176)$ & & \\
\hline $\boldsymbol{B I G 4}$ & $0.312^{* * *}$ & $0.242^{* *}$ & $0.208^{* *}$ & $0.278^{* * *}$ & -0.039 & 1 \\
& $(0.002)$ & $(0.018)$ & $(0.044)$ & $(0.006)$ & $(0.706)$ & \\
\hline
\end{tabular}

Note: Number in parentheses are p-values

$* * *=$ significant at 0.01 level, $* *=$ significant at 0.05 level, $*=$ significant at 0.10 level Variable definitions:

$\mathrm{MV}=$ Number of shares outstanding multiplied by the share price of the firm after issuance of limited review report at the end of Q3 (2020). NI: Net income after tax for the first three quarters of 2020. BV: Book value of equity at the end of Q3 (2020). KAM = 1 if the company receives a modified limited review report with a KAM paragraph on COVID-19 at the end of Q3 (2020), (0) otherwise. LRRL = Natural logarithm of the number of days between the issuance of the interim financial report on the 30th of September 2020 and the limited review report date. BIG4 $=1$ if the company is audited by one of the audit firms affiliated to one of the BIG4 audit firms, (0) otherwise. 


\subsection{Univariate tests}

To examine whether there are significant differences between firms which received a modified limited review report and those which didn't receive it, the researcher split the sample into two subsamples; sample (1) $(\mathrm{KAM}=0)$ (69 firms) and sample (2) $(\mathrm{KAM}=1)(26$ firms) and compared the study variables between the two samples using independent sample t-test.

The results of t-test in table (5) indicate no significant differences between sample $(1)(\mathrm{KAM}=0)$ and sample $(2)(\mathrm{KAM}=1)$ concerning their levels of $M V, N I, B V$ and $L R R L$. This gives first indication that $K A M$ has no significant effect on the perceived quality of interim financial reporting, measured by $M V$. However, the last row of table (5) shows that there is a significant difference between the two samples with regard to $B I G 4$ audit firms and that the number of audit firms affiliated to one of the BIG4 is significantly higher in sample $(2)(\mathrm{KAM}=1)$ than that in sample (1) $(\mathrm{KAM}=0)$. This result indicates that BIG4 audit firms are more likely to issue modified limited review reports because they have more reputation concerns and are more incentivized to provide higher quality audits in less litigious environments to protect their brand name (Khurana and Raman, 2004). 


\begin{tabular}{|c|c|c|c|}
\hline \multicolumn{4}{|c|}{$\begin{array}{l}\text { Table (5) Independent sample t-test (comparing the study } \\
\text { variables between sample (1) KAM = } 0 \text { and sample (2) KAM =1) }\end{array}$} \\
\hline Variable & $\begin{array}{c}\text { Sample (1) } \\
\text { KAM =0 } \\
(\mathrm{N}=69)\end{array}$ & $\begin{array}{c}\text { Sample (2) } \\
\text { KAM = 1 } \\
(\mathrm{N}=\mathbf{2 6})\end{array}$ & $\begin{array}{l}\text { t-statistics for } \\
\text { testing difference } \\
\text { in the mean } \\
\text { Sample (1) - } \\
\text { Sample (2) }\end{array}$ \\
\hline$M V$ & $1,253,262,783$ & 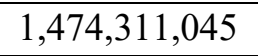 & \\
\hline$N I$ & & & \\
\hline$B V$ & 1,346, & 1,583, & \\
\hline$L R R L$ & & & \\
\hline BIG4 & & & \\
\hline \multicolumn{4}{|c|}{$\begin{array}{l}* * *=\text { significant at } 0.01 \text { level } \\
\text { Variable definitions: } \\
\text { MV = Number of shares outstanding multiplied by the share price of the firm after } \\
\text { issuance of limited review report at the end of Q3 }(2020) \text {. NI: Net income after tax for the } \\
\text { first three quarters of } 2020 \text {. BV: Book value of equity at the end of Q3 }(2020) \text {. LRRL }= \\
\text { Natural logarithm of the number of days between the issuance of the interim financial } \\
\text { report on the } 30^{\text {th }} \text { of September } 2020 \text { and the limited review report date. BIG4 }=1 \text { if the } \\
\text { company is audited by one of the audit firms affiliated to one of the BIG4 audit firms, }(0) \\
\text { otherwise. }\end{array}$} \\
\hline \multicolumn{4}{|c|}{$\begin{array}{l}\text { To examine whether there is significant difference between the } \\
\text { market value of the firms before the issuance of the limited review report } \\
\text { and after its issuance, the researcher used paired sample t-test to examine } \\
\text { the significant difference in market values by comparing the market value } \\
\text { of the firms included in the study after the issuance of the third interim } \\
\text { financial report on September } 30,2020 \text { and the market value of the same } \\
\text { firms after the issuance of the limited review report. As shown in table (6), } \\
\text { the market values of the firms under study have increased significantly } \\
\text { (Sig. = } 0.000 \text { ) after issuing the limited review reports. This result } \\
\text { confirmed the added value of limited review reports and is consistent with } \\
\text { the findings of Manry et al. (2003), which emphasized the importance of } \\
\text { timely reviews of quarterly reports in improving the quality of quarterly } \\
\text { reports and the relevance and reliability of reported earnings. }\end{array}$} \\
\hline
\end{tabular}


Scientific Journal for Financial and Commercial Studies and Researches

Vol.2, No.2, Part 1., July 2021

Dr. Hebatallah Badawy

Table (6) Paired sample t-test (comparing MV before and after the issuance of limited review report)

\begin{tabular}{|c|c|c|c|c|c|c|c|c|}
\hline & & & & $\begin{array}{r}95 \% \text { Confi } \\
\text { of the }\end{array}$ & $\begin{array}{l}\text { nce Interval } \\
\text { fference }\end{array}$ & & & \\
\hline & Mean & $\begin{array}{c}\text { Std. } \\
\text { Deviation }\end{array}$ & $\begin{array}{l}\text { Std. Error } \\
\text { Mean }\end{array}$ & Lower & Upper & $\mathrm{t}$ & df & $\begin{array}{l}\text { Sig. (2- } \\
\text { tailed) }\end{array}$ \\
\hline $\begin{array}{l}\text { MV (after) - } \\
\text { MV (before) }\end{array}$ & $105,493,700$ & $251,300,870$ & $25,782,925$ & $54,301,098$ & $156,686,303$ & 4.092 & 94 & $0.000^{* * *}$ \\
\hline
\end{tabular}

$* * *=$ significant at 0.01 level

To examine whether there is a significant change in the limited review reports at the end of Q3 (2020) in comparison with the same quarter in 2019, the researcher used paired sample t-test to examine whether there is a significant increase in the number of KAM paragraphs related to COVID-19 pandemic and compared the inclusion of KAM paragraph related to COVID-19 pandemic at the end of Q3 (2020) with the same period in 2019. As shown in table (7), it is clear that there is a significant difference in the content of limited review reports in Q3 (2020) in comparison with that at the end of Q3 (2019) (Sig. =0.000). This result indicates that there is a significant increase in the number of firms receiving modified limited review reports in the form of adding a KAM paragraph on COVID-19 pandemic in the limited review report.

Table (7) Paired sample t-test (comparing KAM at the end of Q3-

2020 and at the end of Q3-2019)

\begin{tabular}{|l|c|c|c|c|c|c|c|c|}
\hline & & & & \multicolumn{2}{|c|}{$\begin{array}{c}\text { 95\% Confidence } \\
\text { Interval of the } \\
\text { Difference }\end{array}$} & & & \\
\hline & Mean & $\begin{array}{c}\text { Std. } \\
\text { Deviation }\end{array}$ & $\begin{array}{c}\text { Std. } \\
\text { Error } \\
\text { Mean }\end{array}$ & Lower Upper & $\mathrm{t}$ & $\mathrm{df}$ & $\begin{array}{c}\text { Sig. (2- } \\
\text { tailed) }\end{array}$ \\
\hline $\begin{array}{l}\text { KAM 2020 } \\
\text { KAM } \\
2019\end{array}$ & 0.27368 & 0.44821 & 0.04599 & 0.18238 & 0.36499 & 5.951 & 94 & $0.000^{* * *}$ \\
\hline
\end{tabular}

$* * *=$ significant at 0.01 level. 


\subsection{Hypotheses testing}

To test the effect of limited review report quality $(K A M)$ on the perceived interim financial reporting quality $(M V)$, the researcher ran the first regression model (Model 1). Table (8) showed that the Adj. $\mathrm{R}^{2}$ is $90.7 \%$, which indicates that the $N I, B V$ and $K A M$ can interpret $90.7 \%$ of the changes in the $M V$. It is clear from the table that $N I$ and $B V$ are value relevant and positively and significantly associated with $M V$, however, $K A M$ is negatively but insignificantly associated with $M V(\mathrm{t}=-0.092$, Sig. $=0.927$ ).

This result is consistent with prior research (Bédard, et al. 2014, Lennox et al., 2016; Bédard et al., 2019) that didn't find evidence regarding the information content or communicative value of KAM and didn't find significant effect of adding a KAM paragraph on market reaction or investor response. Additionally, this result provides evidence that KAM paragraph on COVID-19 didn't add additional information to investors and this might be because the information contained in such paragraph is not firm-specific (Gold et al., 2020) or is not presenting additional information other than that included in the interim financial report. That's why the information content of KAM paragraph on COVID19 doesn't increase the level of disclosure or transparency from the investor's point of view.

Accordingly, the first research hypothesis (H1) which expects a positive and significant impact of limited review report quality on the perceived quality of interim financial reporting quality is not supported. 
Scientific Journal for Financial and Commercial Studies and Researches

Vol.2, No.2, Part 1., July 2021

Dr. Hebatallah Badawy

Table (8) Regression results: The effect of KAM on MV (Model 1).

\begin{tabular}{|c|c|c|c|c|c|}
\hline & $\begin{array}{c}\text { Standardized } \\
\text { Coefficients }\end{array}$ & t & Sig. & \multicolumn{2}{c|}{$\begin{array}{c}\text { Collinearity } \\
\text { Statistics }\end{array}$} \\
\hline & Beta & & & Tolerance & VIF \\
\hline (Constant) & & 4.113 & 0.000 & & \\
\hline $\boldsymbol{N I}$ & 0.367 & 8.791 & $0.000^{* * *}$ & 0.566 & 1.766 \\
\hline $\boldsymbol{B} \boldsymbol{V}$ & 0.672 & 16.108 & $0.000^{* * *}$ & 0.568 & 1.760 \\
\hline $\boldsymbol{K} \boldsymbol{A} \boldsymbol{M}$ & -0.003 & -0.092 & 0.927 & 0.996 & 1.004 \\
\hline $\mathrm{R}^{2}$ & \multicolumn{5}{|c|}{0.910} \\
\hline Adj $\mathrm{R}^{2}$ & \multicolumn{5}{|c|}{0.907} \\
\hline F-statistic & 307.013 \\
\hline Durbin & \multicolumn{5}{|c|}{2.216} \\
Watson & \multicolumn{5}{|c|}{$0.000^{* * *}$} \\
\hline Sig. & 95 \\
\hline N & $* * *$ significant at 0.01 level, **= significant at 0.05 level, * significant at 0.10 level
\end{tabular}
Variable definitions:

NI: Net income after tax for the first three quarters of 2020. BV: Book value of equity at the end of Q3 (2020). KAM = 1 if the company receives a modified limited review report with a KAM paragraph on COVID-19 at the end of Q3 (2020), (0) otherwise.

To test the effect of the timeliness of limited review report $(L R R L)$ on the perceived quality of interim financial reporting $(M V)$, the researcher ran the second regression model (Model 2) and found in table (9) that the Adj. $\mathrm{R}^{2}$ is $92 \%$, which indicates that the NI, $B V$ and $L R R L$ can interpret $92 \%$ of the changes in the $M V$. It is clear from the table that $N I$ and $B V$ are positively and significantly associated with $M V$, and that $L R R L$ is negatively and significantly associated with $M V(\mathrm{t}=-3.752$, Sig. $=0.000)$.

This result is inconsistent with that of Akeem et al. (2020) that didn't find significant effect of ARL on the firms' market values in the food and beverage industry in Nigeria. On the other side, the regression result indicates that investors in Egypt value timely interim financial reports and limited review reports, especially in the time of crisis in order 
to take informed decisions and reduce the level of uncertainty related to the firms' operations and reaction to COVID-19 pandemic. In other words, the delays in issuing limited review reports in times of crisis will increase investors' suspicions regarding management performance and this will be reflected negatively on the market values.

As $L R R L$ represents the delay in issuing the limited review reports and this reduces the timeliness of such reports, the result in table (9) supports the second research hypothesis $(\mathrm{H} 2)$ which expects that the timeliness of the limited review report will have a positive and significant impact on the perceived quality of interim financial reporting.

Table (9) Regression results: The effect of LRRL on MV (Model 2).

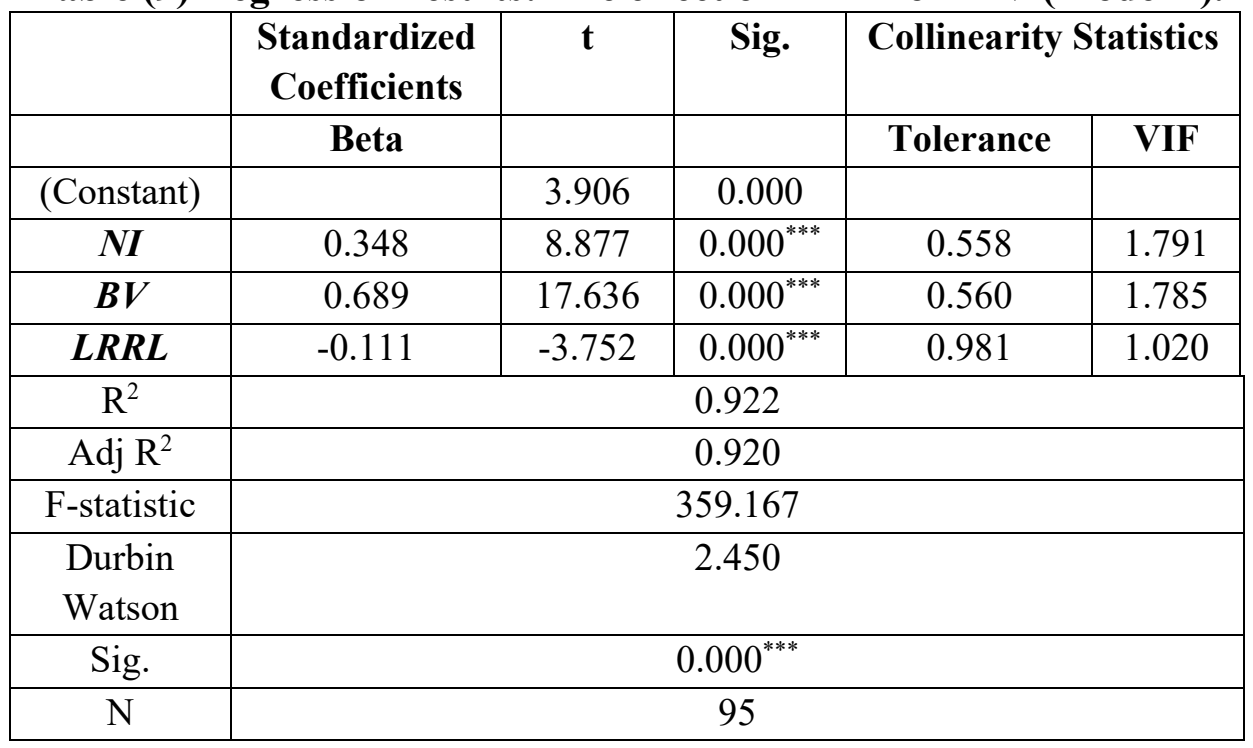

$* * *=$ significant at 0.01 level, $* *=$ significant at 0.05 level, $*=$ significant at 0.10 level Variable definitions:

NI: Net income after tax for the first three quarters of 2020. BV: Book value of equity at the end of Q3 (2020). LRRL = Natural logarithm of the number of days between the issuance of the interim financial report on the $30^{\text {th }}$ of September 2020 and the limited review report date. 
To test the effect of both $K A M$ and $L R R L$ on $M V$, the researcher used the third regression model (Model 3), and as presented in table (10), confirmed the results above that $N I(\mathrm{t}=8.776$, Sig. $=0.000)$ and $B V(\mathrm{t}=$ 17.564, Sig. $=0.000)$ are positively and significantly associated with $M V$. $K A M$ was found to be positively but insignificantly associated with $M V$ ( $\mathrm{t}$ $=0.461$, Sig. $=0.646)$ and $L R R L$ was found to be negatively and significantly associated with $M V(\mathrm{t}=-3.763$, Sig. $=0.000)$.

The regression results in table (10) show that investors demand timely financial information presented in the interim financial reports and the limited review reports in order to take informed and rational investment decisions and update their previous decisions, especially during COVID19 pandemic crisis. Meanwhile, regression results show that $K A M$ paragraph on COVID-19 pandemic added to the limited review report doesn't have informational value from the investors' point of view. This result might be because $K A M$ paragraph on COVID-19 is not firm specific (Gold et al., 2020) and is standardized and therefore doesn't add any further disclosure more than that presented in the interim financial reports. 
Scientific Journal for Financial and Commercial Studies and Researches

Vol.2, No.2, Part 1., July 2021

Dr. Hebatallah Badawy

Table (10) Regression results: The effect of KAM and LRRL on MV

(Model 3) (Basic Model)

\begin{tabular}{|c|c|c|c|c|c|}
\hline & Standardized Coefficients & $\mathbf{t}$ & Sig. & \multicolumn{2}{|c|}{ Collinearity Statistics } \\
\hline & Beta & & & Tolerance & VIF \\
\hline (Constant) & & 3.916 & 0.000 & & \\
\hline NI & 0.346 & 8.776 & $0.000^{* * *}$ & 0.555 & 1.802 \\
\hline$B V$ & 0.690 & 17.564 & $0.000^{* * *}$ & 0.560 & 1.787 \\
\hline$K A M$ & 0.014 & 0.461 & 0.646 & 0.974 & 1.026 \\
\hline LRRL & -0.113 & -3.763 & $0.000^{* * *}$ & 0.959 & 1.042 \\
\hline $\mathrm{R}^{2}$ & \multicolumn{5}{|c|}{0.922} \\
\hline Adj $R^{2}$ & \multicolumn{5}{|c|}{0.919} \\
\hline F-statistic & \multicolumn{5}{|c|}{267.098} \\
\hline Durbin Watson & \multicolumn{5}{|c|}{2.417} \\
\hline Sig. & \multicolumn{5}{|c|}{$0.000^{* * *}$} \\
\hline $\mathrm{N}$ & \multicolumn{5}{|c|}{95} \\
\hline \multicolumn{6}{|c|}{$\begin{array}{l}\text { NI: Net income after tax for the first three quarters of } 2020 \text {. BV: Book value of equity at } \\
\text { the end of Q3 (2020). KAM }=1 \text { if the company receives a modified limited review report } \\
\text { with a KAM paragraph on COVID-19 at the end of Q3 }(2020),(0) \text { otherwise. LRRL = } \\
\text { Natural logarithm of the number of days between the issuance of the interim financial } \\
\text { report on the 30th of September } 2020 \text { and the limited review report date. }\end{array}$} \\
\hline
\end{tabular}

\subsection{Other Analyses}

\subsubsection{Adding audit firm size as a proxy of limited review quality to the basic regression model}

To test the effect of audit firm size (BIG4), as a proxy of limited review quality, on the perceived interim financial reporting quality $(M V)$, the researcher ran the fourth regression model (Model 4) and found in table (11) that the Adj. $\mathrm{r}^{2}$ increased slightly from $91.9 \%$ to $92.5 \%$.

Consistent with the above results, $N I(\mathrm{t}=8.715$, Sig. $=0.000)$ and $B V(\mathrm{t}=17.982$, Sig. $=0.000)$ are value relevant and are positively and significantly associated with $M V . K A M$ is found to be negatively but insignificantly associated with $M V(\mathrm{t}=-0.365$, Sig. $=0.716)$, showing that $K A M$ doesn't add additional value or information to investors other than that presented by managers in the interim financial reports. 
Table (11) shows that $B I G 4$ is positively and significantly associated with $M V(\mathrm{t}=2.930, \mathrm{Sig} .=0.004)$, indicating that investors value audit firm size (as a proxy of limited review quality) and their confidence in the firms' performance increases when the interim financial reports are reviewed by an audit firm affiliated to one of the BIG4. Finally, regression results reveal that $L R R L$ is negatively and significantly associated with $M V$ $(\mathrm{t}=-3.688$, Sig. $=0.000)$, which means that timeliness of limited reviews is highly appreciated from the investors' point of view and this confirms the expectation that investors, in time of crisis, demands more frequent financial reports more than ever before.

Table (11) Regression results: The effect of adding BIG4 to the basic regression model (Model 4)

\begin{tabular}{|c|c|c|c|c|c|}
\hline & Standardized Coefficients & $\mathbf{t}$ & Sig. & \multicolumn{2}{|c|}{ Collinearity Statistics } \\
\hline & Beta & & & Tolerance & VIF \\
\hline (Constant) & & 3.829 & 0.000 & & \\
\hline$N I$ & 0.333 & 8.715 & $0.000^{* * *}$ & 0.547 & 1.829 \\
\hline$B V$ & 0.681 & 17.982 & $0.000^{* * *}$ & 0.556 & 1.800 \\
\hline $\boldsymbol{K A M}$ & -0.011 & -0.365 & 0.716 & 0.897 & 1.115 \\
\hline LRRL & -0.107 & -3.688 & $0.000^{* * *}$ & 0.954 & 1.048 \\
\hline BIG4 & 0.089 & 2.930 & $0.004^{* * *}$ & 0.862 & 1.160 \\
\hline $\mathrm{R}^{2}$ & \multicolumn{5}{|c|}{0.929} \\
\hline Adj $R^{2}$ & \multicolumn{5}{|c|}{0.925} \\
\hline F-statistic & \multicolumn{5}{|c|}{233.409} \\
\hline Durbin Watson & \multicolumn{5}{|c|}{2.426} \\
\hline Sig. & \multicolumn{5}{|c|}{$0.000^{* * *}$} \\
\hline $\mathrm{N}$ & \multicolumn{5}{|c|}{95} \\
\hline \multicolumn{6}{|c|}{$\begin{array}{l}* * *=\text { significant at } 0.01 \text { level, } * *=\text { significant at } 0.05 \text { level, } *=\text { significant at } 0.10 \text { level } \\
\text { Variable definitions: } \\
N I \text { : Net income after tax for the first three quarters of } 2020 . B V \text { : Book value of equity at } \\
\text { the end of Q3 }(2020) . K A M=1 \text { if the company receives a modified limited review report } \\
\text { with a KAM paragraph on COVID-19 at the end of Q3 }(2020),(0) \text { otherwise. } L R R L= \\
\text { Natural logarithm of the number of days between the issuance of the interim financial } \\
\text { report on the } 30^{\text {th }} \text { of September } 2020 \text { and the limited review report date. } B I G 4=1 \text { if the } \\
\text { company is audited by one of the audit firms affiliated to one of the BIG4 audit firms, (0) } \\
\text { otherwise. }\end{array}$} \\
\hline
\end{tabular}




\subsubsection{KAM as a moderating variable}

To test the moderating effect of $K A M$ on $M V$ in the basic model, the researcher ran the fifth regression model (Model 5) and found in table (12) that $N I(\mathrm{t}=7.701$, Sig. $=0.000)$ and $B V(\mathrm{t}=14.799$, Sig. $=0.000)$ are still positively and significantly associated with $M V$. Table (12) shows that $K A M(\mathrm{t}=-0.005$, Sig. $=0.996)$, and the interactive variables $\left(K A M^{*} N I\right)(\mathrm{t}$ $=-0.571$, Sig. $=0.596)$ and $\left(K A M^{*} B V\right)(\mathrm{t}=0.193$, Sig. $=0.847)$ are insignificantly associated with $M V$.

This result shows that $K A M$ is not value relevant and not reflected in the market values of firms and at the same time, it doesn't have significant effect on the relationship between $N I$ and $B V$ on one side and the quality of interim financial reporting, $M V$, on the other side.

Table (12) Regression results: The moderating effect of KAM on MV in the basic model (Model 5).

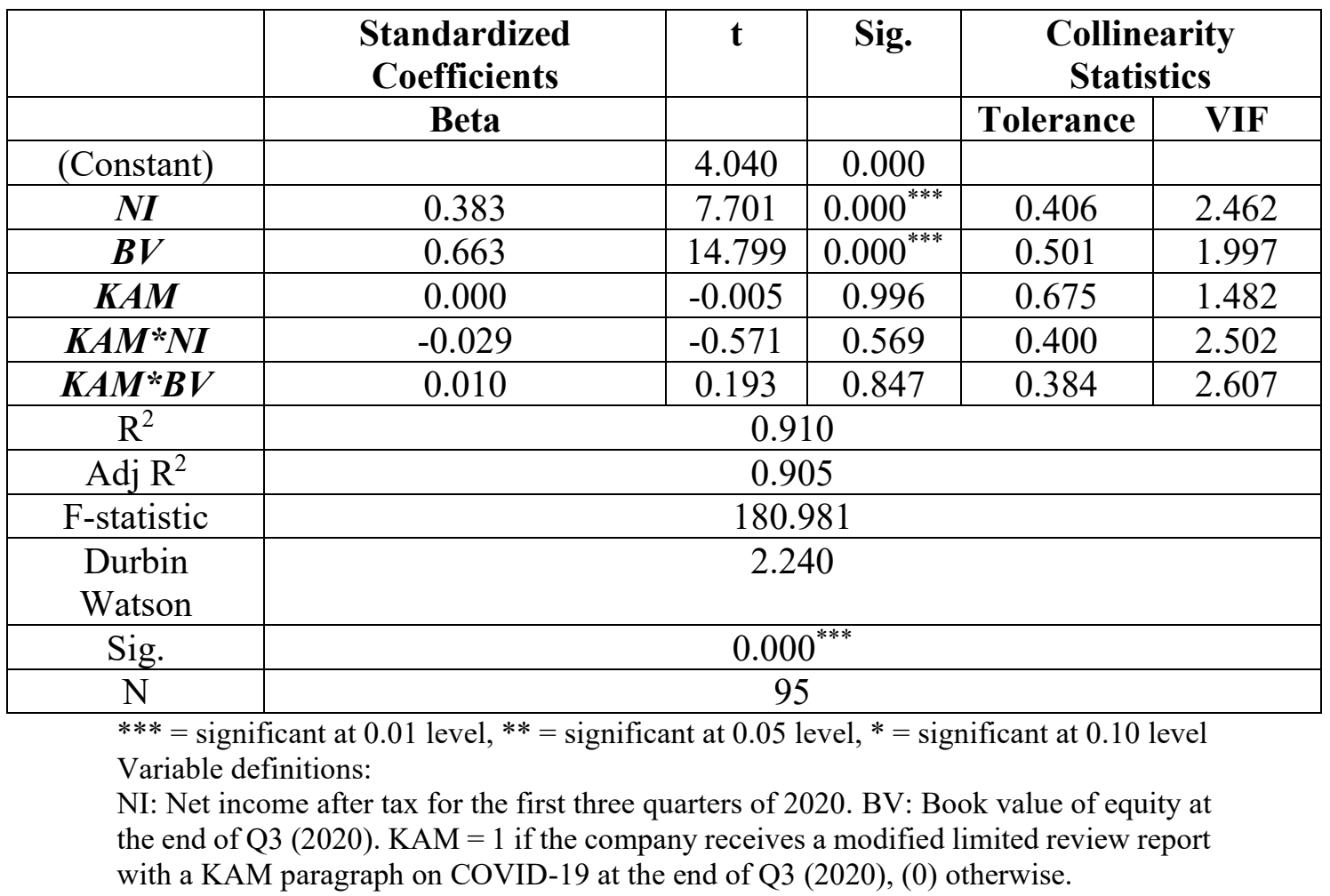


To test the moderating effect of $K A M$ on $M V$ in the extended model, the researcher ran the sixth regression model (Model 6) and, consistent with the results above, found in table (13) that $N I$ and $B V$ are still positively and significantly associated with $M V . K A M(\mathrm{t}=-0.325$, Sig. $=0.746), K A M^{*} N I(\mathrm{t}=-0.537$, Sig. $=0.593)$ and $K A M^{*} B V(\mathrm{t}=0.366$, Sig. $=0.715)$ are not significantly associated with $M V$. Also, it is clear that $B I G 4$ is positively and significantly associated with $M V(\mathrm{t}=2.724$, Sig. $=$ $0.008)$, and $L R R L$ is negatively and significantly associated with $M V(\mathrm{t}=$ 3.691, Sig. $=0.000)$.

Table (13) Regression results: The moderating effect of KAM on MV in the extended model (Model 6).

\begin{tabular}{|c|c|c|c|c|c|}
\hline & Standardized Coefficients & $\mathbf{t}$ & Sig. & \multicolumn{2}{|c|}{ Collinearity Statistics } \\
\hline & Beta & & & Tolerance & VIF \\
\hline (Constant) & & 3.829 & 0.000 & & \\
\hline NI & 0.345 & 7.509 & $0.000^{* * *}$ & 0.385 & 2.597 \\
\hline$B V$ & 0.674 & 16.681 & $0.000^{* * *}$ & 0.498 & 2.009 \\
\hline KAM & -0.012 & -0.325 & 0.746 & 0.614 & 1.629 \\
\hline$K A M * N I$ & -0.025 & -0.537 & 0.593 & 0.378 & 2.647 \\
\hline$K A M * B V$ & 0.017 & 0.366 & 0.715 & 0.381 & 2.627 \\
\hline$L R R L$ & -0.109 & -3.691 & $0.000^{* * *}$ & 0.936 & 1.069 \\
\hline BIG4 & 0.086 & 2.724 & $0.008^{* * *}$ & 0.819 & 1.221 \\
\hline $\mathrm{R}^{2}$ & \multicolumn{5}{|c|}{0.929} \\
\hline Adj $R^{2}$ & \multicolumn{5}{|c|}{0.924} \\
\hline F-statistic & \multicolumn{5}{|c|}{163.559} \\
\hline Durbin Watson & \multicolumn{5}{|c|}{2.437} \\
\hline Sig. & \multicolumn{5}{|c|}{$0.000^{* * *}$} \\
\hline $\mathrm{N}$ & \multicolumn{5}{|c|}{95} \\
\hline \multicolumn{6}{|c|}{$\begin{array}{l}* * *=\text { significant at } 0.01 \text { level, } * *=\text { significant at } 0.05 \text { level, }{ }^{*}=\text { significant at } 0.10 \text { level } \\
\text { Variable definitions: } \\
\text { NI: Net income after tax for the first three quarters of } 2020 . \mathrm{BV} \text { : Book value of equity at } \\
\text { the end of Q3 }(2020) \text {. KAM }=1 \text { if the company receives a modified limited review report } \\
\text { with a KAM paragraph on COVID- } 19 \text { at the end of Q3 }(2020),(0) \text { otherwise. LRRL }= \\
\text { Natural logarithm of the number of days between the issuance of the interim financial } \\
\text { report on the 30th of September } 2020 \text { and the limited review report date. BIG }=1 \text { if the } \\
\text { company is audited by one of the audit firms affiliated to one of the BIG4 audit firms, }(0) \\
\text { otherwise. }\end{array}$} \\
\hline
\end{tabular}




\subsubsection{Dividing the sample according to KAM}

The researcher in this additional analysis divided the sample into two subsamples, the first one represents the firms that didn't receive a limited review report with a $K A M$ on COVID-19 pandemic (sample 1) (69 firms) and the second one represents the firms that received a limited review report with a $K A M$ on COVID-19 pandemic (sample 2) (26 firms). Table (14) shows that, for sample (1), NI ( $\mathrm{t}=7.032$, Sig. $=0.000), B V(\mathrm{t}=$ 17.244, Sig. $=0.000)$ and $B I G 4(\mathrm{t}=3.771$, Sig. $=0.000)$ are positively and significantly associated with $M V$ and $L R R L$ is negatively and significantly associated with $M V(\mathrm{t}=-2.417$, Sig. $=0.018)$. As for sample (2), which receives a modified limited review report with a $K A M$ paragraph on COVID-19 pandemic, table (14) reveals the same results as that of sample (1), except that $B I G 4$ turned to be positively but insignificantly associated with $M V(\mathrm{t}=1.063$, Sig. $=0.300)$. This result indicates that for those firms that receive a $K A M$ paragraph on COVID-19, investors are not affected by the audit firm size.

Also, the results in table (14) shows that for sample (1), $N I, B V$, $L R R L$ and $B I G 4$ can interpret $94.3 \%$ of the changes in $M V$, however, for sample (2), those variables can interpret $83.4 \%$ of the changes in $M V$. Finally, table (14) reveals that the impact of $N I$ and $B V$ on $M V$ are greater in sample $(1)(\mathrm{KAM}=0)$ than that in sample $(2)(\mathrm{KAM}=1)$ and the impact of $L R R L$ on $M V$ is greater in sample (2) $(\mathrm{t}=-3.246$, Sig. $=0.004)$ than that in sample $(1)(t=-2.417$, Sig. $=0.018)$. This result provides evidence that investors are more negatively and significantly affected by the delay in issuing the modified limited review report with a KAM paragraph on COVID-19 in comparison with the case of not including such paragraph in the limited review report. 
Scientific Journal for Financial and Commercial Studies and Researches

Vol.2, No.2, Part 1., July 2021

Dr. Hebatallah Badawy

Table (14) Regression results: Dividing the full sample into two

subsamples based on KAM

\begin{tabular}{|c|c|c|c|c|c|c|c|c|c|c|}
\hline & \multicolumn{5}{|c|}{$\mathbf{K A M}=\mathbf{0}$} & \multicolumn{5}{|c|}{$\mathbf{K A M}=1$} \\
\hline & $\begin{array}{l}\text { Standa } \\
\text { rdized }\end{array}$ & $\mathbf{t}$ & Sig. & \multicolumn{2}{|c|}{$\begin{array}{l}\text { Collinearity } \\
\text { Statistics }\end{array}$} & $\begin{array}{l}\text { Standardi } \\
\text { zed }\end{array}$ & $\mathbf{t}$ & Sig. & \multicolumn{2}{|c|}{$\begin{array}{l}\text { Collinearity } \\
\text { Statistics }\end{array}$} \\
\hline & Beta & & & Tolerance & VIF & Beta & & & Tolerance & VIF \\
\hline (Constant) & & 2.535 & 0.014 & & & & 3.290 & 0.003 & & \\
\hline NI & 0.296 & 7.032 & $0.000^{* * *}$ & 0.473 & 2.115 & 0.286 & 2.337 & $0.029^{* *}$ & 0.443 & 2.258 \\
\hline$B V$ & 0.688 & 17.244 & $0.000^{* * *}$ & 0.526 & 1.902 & 0.606 & 5.460 & $0.000^{* * *}$ & 0.539 & 1.855 \\
\hline LRRL & -0.072 & -2.417 & $0.018^{* *}$ & 0.938 & 1.067 & -0.313 & -3.246 & $0.004^{* * *}$ & 0.712 & 1.405 \\
\hline BIG4 & 0.125 & 3.771 & $0.000^{* * *}$ & 0.762 & 1.313 & 0.090 & 1.063 & 0.300 & 0.935 & 1.069 \\
\hline $\mathrm{R}^{2}$ & \multicolumn{5}{|c|}{0.946} & \multicolumn{5}{|c|}{0.861} \\
\hline $\operatorname{Adj} R^{2}$ & \multicolumn{5}{|c|}{0.943} & \multicolumn{5}{|c|}{0.834} \\
\hline F-statistic & \multicolumn{5}{|c|}{282.626} & \multicolumn{5}{|c|}{32.445} \\
\hline $\begin{array}{l}\text { Durbin } \\
\text { Watson } \\
\end{array}$ & \multicolumn{5}{|c|}{2.382} & \multicolumn{5}{|c|}{2.475} \\
\hline Sig. & \multicolumn{5}{|c|}{$0.000^{* * *}$} & \multicolumn{5}{|c|}{$0.000^{* * *}$} \\
\hline $\mathrm{N}$ & \multicolumn{5}{|c|}{69} & \multicolumn{5}{|c|}{26} \\
\hline
\end{tabular}

$* * *=$ significant at 0.01 level, $* *=$ significant at 0.05 level, $*=$ significant at 0.10 level Variable definitions:

NI: Net income after tax for the first three quarters of 2020. BV: Book value of equity at the end of Q3 (2020). LRRL = Natural logarithm of the number of days between the issuance of the interim financial report on the 30th of September 2020 and the limited review report date. $\mathrm{BIG} 4=1$ if the company is audited by one of the audit firms affiliated to one of the BIG4 audit firms, (0) otherwise.

\subsubsection{Stepwise Regression}

To identify the most influential variables, the researcher ran stepwise regression. The results of the stepwise regression in table (15) reveal that $K A M$ is not among the influential variables that affect the perceived interim financial reporting quality and that $B V(\mathrm{t}=18.123$, Sig. $=0.000)$ is the most influential variable and then come $N I(\mathrm{t}=8.794$, Sig. $=0.000), \operatorname{LRRL}(\mathrm{t}=-3.817$, Sig. $=0.000)$ and BIG4 $(\mathrm{t}=2.961$, Sig. $=$ $0.004)$. Stepwise regression results confirmed the research results reached above, which show that timeliness of limited review report is highly valued by investors and that KAM is not significantly affecting the perceived quality of interim financial reporting. 
Scientific Journal for Financial and Commercial Studies and Researches

Vol.2, No.2, Part 1., July 2021

Dr. Hebatallah Badawy

Table (15): Stepwise regression

\begin{tabular}{|c|c|c|c|c|c|}
\hline & $\begin{array}{l}\text { Standardized } \\
\text { Coefficients }\end{array}$ & $\mathbf{t}$ & Sig. & \multicolumn{2}{|c|}{$\begin{array}{c}\text { Collinearity } \\
\text { Statistics }\end{array}$} \\
\hline & Beta & & & Tolerance & VIF \\
\hline (Constant) & & 3.945 & 0.000 & & \\
\hline$N I$ & 0.332 & 8.749 & $0.000^{* * *}$ & 0.548 & 1.826 \\
\hline $\boldsymbol{B} \boldsymbol{V}$ & 0.682 & 18.123 & $0.000^{* * *}$ & 0.558 & 1.793 \\
\hline LRRL & -0.108 & -3.817 & $0.000^{* * *}$ & 0.980 & 1.020 \\
\hline BIG4 & .086 & 2.961 & $0.004^{* * *}$ & 0.936 & 1.068 \\
\hline $\mathrm{R}^{2}$ & \multicolumn{5}{|c|}{0.929} \\
\hline $\operatorname{Adj~} R^{2}$ & \multicolumn{5}{|c|}{0.926} \\
\hline F-statistic & \multicolumn{5}{|c|}{294.566} \\
\hline $\begin{array}{l}\text { Durbin } \\
\text { Watson }\end{array}$ & \multicolumn{5}{|c|}{2.324} \\
\hline Sig. & \multicolumn{5}{|c|}{$0.000^{* * *}$} \\
\hline $\mathrm{N}$ & \multicolumn{5}{|c|}{95} \\
\hline \multicolumn{6}{|c|}{$\begin{array}{l}* * *=\text { significant at } 0.01 \text { level, } * *=\text { significant at } 0.05 \text { level, }{ }^{*}=\text { significant at } 0.10 \text { level } \\
\text { Variable definitions: } \\
\text { NI: Net income after tax for the first three quarters of } 2020 . \text { BV: Book value of equity at } \\
\text { the end of Q3 }(2020) \text {. LRRL }=\text { Natural logarithm of the number of days between the } \\
\text { issuance of the interim financial report on the } 30 \text { th of September } 2020 \text { and the limited } \\
\text { review report date. BIG4 }=1 \text { if the company is audited by one of the audit firms affiliated } \\
\text { to one of the BIG4 audit firms, (0) otherwise. }\end{array}$} \\
\hline
\end{tabular}

\subsubsection{Alternative measure of perceived interim financial reporting quality}

To test the robustness of the results, the researcher run the sixth regression model (Model 6) using per share measures shown in Ohlson Model (Ohlson, 1995). The researcher measured the perceived interim financial reporting quality using the firm's share price following the issuance of the limited review report $(S P)$, and the EPS and $B V S$ are used in the regression model instead of $N I$ and $B V$ (Okolie \& Izedonmi, 2014; Abdollahi et al., 2020). 
Consistent with Ianniello \& Galloppo (2020), table (16) shows that $K A M$ is positively and significantly associated with the perceived quality of interim financial reports (measured by $S P)$ at 5\% significance level $(\mathrm{t}=$ 2.049, Sig. $=0.044)$. This result shows that when using $S P$ as a measure of perceived quality of interim financial reporting, the modified limited review report (KAM) will have information content to investors and increase the level of transparency and disclosure, which in turn will help in reducing information asymmetry level.

According to table (16), EPS turned to be negatively and significantly associated with $S P(\mathrm{t}=-4.412$, Sig. $=0.000)$. This result might indicate investors' suspicions and lack of confidence in the firms' earnings and financial performance during COVID-19 pandemic crisis, especially that this crisis has its severe impact on nearly all sectors and affected their level of revenues, profits and financial performance in general. On the other hand, the interactive variable $\left(K A M^{*} E P S\right)$ is positively and significantly associated with $S P(\mathrm{t}=6.539$, Sig. $=0.000)$, indicating that when adding a $K A M$ paragraph on COVID-19 pandemic to the limited review report, EPS will have a positive and significant effect on $S P$ and investors' confidence in the firm performance will increase. This result confirmed the added value of $K A M$ from the investors' point of view. 
Scientific Journal for Financial and Commercial Studies and Researches

Vol.2, No.2, Part 1., July 2021

Dr. Hebatallah Badawy

Table (16): Sensitivity analysis (alternative measure of perceived interim financial reporting quality)

\begin{tabular}{|c|c|c|c|c|c|}
\hline & $\begin{array}{c}\text { Standardized } \\
\text { Coefficients }\end{array}$ & $\mathbf{t}$ & Sig. & \multicolumn{2}{|c|}{$\begin{array}{c}\text { Collinearity } \\
\text { Statistics }\end{array}$} \\
\hline & Beta & & & Tolerance & VIF \\
\hline (Constant) & & 0.644 & 0.521 & & \\
\hline EPS & -0.155 & -4.412 & $0.000^{* * * *}$ & 0.484 & 2.066 \\
\hline$B V S$ & 0.940 & 27.640 & $0.000^{* * *}$ & 0.517 & 1.936 \\
\hline $\boldsymbol{K} \boldsymbol{A} \boldsymbol{M}$ & 0.060 & 2.049 & $0.044^{* *}$ & 0.688 & 1.453 \\
\hline$K A M * E P S$ & 0.201 & 6.539 & $0.000^{* * *}$ & 0.634 & 1.577 \\
\hline$K A M * B V S$ & -0.272 & -8.536 & $0.000^{* * *}$ & 0.586 & 1.705 \\
\hline LRRL & -0.017 & -0.691 & 0.491 & 0.963 & 1.038 \\
\hline BIG4 & -0.018 & -0.683 & 0.497 & 0.904 & 1.107 \\
\hline $\mathrm{R}^{2}$ & \multicolumn{5}{|c|}{0.948} \\
\hline Adj $R^{2}$ & \multicolumn{5}{|c|}{0.944} \\
\hline F-statistic & \multicolumn{5}{|c|}{226.781} \\
\hline Durbin Watson & \multicolumn{5}{|c|}{2.003} \\
\hline Sig. & \multicolumn{5}{|c|}{$0.000^{* * *}$} \\
\hline $\mathrm{N}$ & \multicolumn{5}{|c|}{95} \\
\hline
\end{tabular}

Variable definitions:

EPS: Net income after tax for the first three quarters of 2020 divided by the number of shares outstanding at the end of the third quarter of 2020. BVS: Book value of equity at the end of Q3 (2020) divided by the number of shares outstanding at the end of the third quarter of 2020. KAM $=1$ if the company receives a modified limited review report with a KAM paragraph on COVID-19 at the end of Q3 (2020), (0) otherwise. LRRL = Natural logarithm of the number of days between the issuance of the interim financial report on the 30th of September 2020 and the limited review report date. BIG4 = 1 if the company is audited by one of the audit firms affiliated to one of the BIG4 audit firms, (0) otherwise.

On the other hand, table (16) reveals that $B V S$ is showing positive and significant association with $S P(\mathrm{t}=27.640$, Sig. $=0.000)($ consistent with the results shown above) and that the interactive variable $\left(K A M^{*} B V S\right)$ is negatively and significantly associated with $S P(\mathrm{t}=-8.536$, Sig. $=0.000)$, indicating that in the presence of $K A M$ paragraph on COVID-19, $B V S$ will be negatively and significantly associated with $S P$. This result confirmed the significant effect of $K A M$ on $S P$, showing that $K A M$ paragraph reversed the positive impact of $B V S$ and the negative impact of $E P S$ on $S P$. 
Concerning the impact of limited review report timeliness (LRRL) on the perceived quality of interim financial reporting, Table (16) shows that $L R R L$ is negatively but insignificantly associated with $S P(\mathrm{t}=-0.691$, Sig. $=0.491)$. In addition, consistent with Sutthipan (2020) and in contrast with Okolie \& Izedonmi (2014), BIG4 $(\mathrm{t}=-0.683$, Sig. $=0.497)$ is not significantly associated with $S P$.

\subsubsection{Alternative measure of the timeliness of limited review report}

In this sensitivity analysis, the researcher ran the fourth regression model (Model 4) and relied on the number of days that elapsed between the date of interim financial report (Sep. $\left.30^{\text {th }}, 2020\right)$ and the date of the limited review report to measure $L R R L$.

Table (17) confirmed the above results and showed that $N I(\mathrm{t}=8.496$, Sig. $=0.000), B V(\mathrm{t}=17.662$, Sig. $=0.000)$ and $B I G 4(\mathrm{t}=3.053$, Sig. $=0.003)$ are positively and significantly associated with $M V$ and $L R R L(\mathrm{t}=-3.226$, Sig. $=0.002)$ is negatively and significantly associated with $M V$, indicating that the timeliness of limited review reports is highly valued by investors during COVID-19 pandemic crisis. In addition, and consistent with main study findings, $K A M(\mathrm{t}=-0.426$, Sig. 0.671$)$ is shown to be insignificantly associated with $M V$. 
Scientific Journal for Financial and Commercial Studies and Researches

Vol.2, No.2, Part 1., July 2021

Dr. Hebatallah Badawy

Table (17): Sensitivity analysis (alternative measure of the timeliness

of limited review report)

\begin{tabular}{|c|c|c|c|c|c|}
\hline & $\begin{array}{c}\text { Standardized } \\
\text { Coefficients }\end{array}$ & $\mathbf{t}$ & Sig. & \multicolumn{2}{|c|}{$\begin{array}{c}\text { Collinearity } \\
\text { Statistics }\end{array}$} \\
\hline & Beta & & & Tolerance & VIF \\
\hline (Constant) & & 3.647 & 0.000 & & \\
\hline NI & 0.331 & 8.496 & $0.000^{*-1}$ & 0.542 & 1.845 \\
\hline$B \bar{V}$ & 0.681 & 17.662 & $0.000^{\circ}$ & 0.553 & 1.808 \\
\hline $\boldsymbol{K A M}$ & -0.013 & -0.426 & 0.671 & 0.897 & 1.115 \\
\hline LRRL & -0.095 & -3.226 & $0.002^{*}$ & 0.948 & 1.055 \\
\hline BIG4 & 0.094 & 3.053 & $0.003^{*}$ & 0.866 & 1.155 \\
\hline $\mathrm{R}^{2}$ & \multicolumn{5}{|c|}{0.927} \\
\hline Adj $R^{2}$ & \multicolumn{5}{|c|}{0.923} \\
\hline F-statistic & \multicolumn{5}{|c|}{225.583} \\
\hline $\begin{array}{l}\text { Durbin } \\
\text { Watson }\end{array}$ & \multicolumn{5}{|c|}{2.283} \\
\hline Sig. & \multirow{2}{*}{\multicolumn{5}{|c|}{$\begin{array}{c}0.000^{\text {*a* }} \\
95\end{array}$}} \\
\hline $\mathrm{N}$ & & & & & \\
\hline
\end{tabular}

$* * *=$ significant at 0.01 level, $* *=$ significant at 0.05 level, $*=$ significant at 0.10 leve Variable definitions:

NI: Net income after tax for the first three quarters of 2020. BV: Book value of equity at the end of Q3 (2020). KAM = 1 if the company receives a modified limited review report with a KAM paragraph on COVID-19 at the end of Q3 (2020), (0) otherwise. LRRL = The number of days between the issuance of the interim financial report on the 30th of September 2020 and the limited review report date. BIG4 $=1$ if the company is audited by one of the audit firms affiliated to one of the BIG4 audit firms, (0) otherwise.

\section{Conclusions, recommendations and implications for future research}

The objective of this study is to investigate and analyze the impact of quality and timeliness of limited review reports on the perceived quality of interim financial reporting during COVID-19 pandemic crisis in Egypt. To fulfil the research objective, the researcher reviewed prior literature related to the quality and timeliness of audit and limited review reports and their impact on the quality of financial reporting from the investors' point of view.

The researcher hypothesized that the quality of limited review report and its information content (measured by adding a KAM paragraph on COVID-19 pandemic to the limited review report) will be positively associated with the perceived quality of interim financial reporting, 
measured by the market value of firms listed on the EGX and that the timeliness of limited review report (as measured by limited review report lag) will be positively and significantly associated with the perceived quality of interim financial reporting during the COVID-19 pandemic crisis. Because the research focused on the investors' point of view, the researcher measured the perceived quality of interim financial reporting by the market value of the firms' outstanding shares.

Based on a sample of 95 non-financial firms listed on the EGX at the end of the third quarter in 2020 , the researcher found evidence that the timeliness of limited review reports is highly valued by investors in Egypt. This result confirmed the expectation that during crisis, investors' demand of audited and high-quality financial information increases in order to reduce the level of information asymmetry and increase their confidence in the firms' operations. Also, timely information will help investors to be updated and to revisit their prior investment decisions. This result is valid when LRRL is measured using the number of days that elapse between the interim financial report date at the end of the third quarter in 2020 and the limited review report date or the natural logarithm of these days.

On the other hand, the researcher didn't find evidence that investors in Egypt value the quality of limited review reports, measured by adding a KAM paragraph related to COVID-19 pandemic to the limited review reports. This result indicates that KAM paragraph is not as informative as expected by standard setters and regulators. KAM paragraph related to COVID-19 pandemic doesn't add information to investors other than that included in the interim financial reports and this might be because this paragraph is standardized and not firm-specific. It is important to note that this result is valid when the researcher used the market value of firms to measure the perceived quality of interim financial reports, however, when the share price of firms was used as an alternative measure of the perceived quality of interim financial reports, the researcher found evidence that KAM has its positive and significant impact on the interim financial reporting quality from the investors' point of view. 
Concerning the control variables, the researcher found that firms' net income, book value of equity and audit firm size are positively and significantly associated with the perceived quality of interim financial reporting from the investors' point of view. Given the scarcity of evidence on the relationship being studied in this research, its results provide useful insights into the impact of limited review report on the quality of interim financial reports from the investors' point of view during COVID-19 pandemic crisis in a developing country, Egypt.

The findings of this study should be considered in the light of its limitations. One limitation is the lack of a very large data set of interim financial reports issued at the end of the third quarter of 2020, as although the study covers 180 non-financial firms, the final sample includes 95 firms only, which means that nearly half of the data is unavailable. Second, adding firm related variables and measures, such as firm size, liquidity and risk levels to the regression model in future research may add further evidence, as they are of higher importance to investors and may affect their valuation of firms. Finally, financial companies are excluded from this study due to their different nature of operation and regulatory environment.

The researcher recommends more attention to be paid to the role of KAM paragraph in enhancing the quality of limited review reports, increasing the level of financial disclosure and transparency and reducing the level of information asymmetry and the information gap between the auditors and the users of interim financial reports in general, and the investors in particular. It is important to emphasize that such paragraph is not a repetition of what is presented by the firm in its financial reports.

It will be interesting if future research investigates the impact of other quality measures of limited review reports, such as the quality of the process itself and the different review procedures on the quality of interim financial reports from other stakeholders' point of view, such as that of financial analysts or creditors. In addition, the researcher recommends future studies to examine the impact of the quality of limited review reports on the quality of interim financial reports in the banking sector, especially that this sector is severely affected by COVID-19 pandemic crisis. Finally, future research might examine the abovementioned relationship while considering good corporate governance or ownership structure as a moderating variable. 


\section{References}

Abdollahi, A., Pitenoei, Y. \& Gerayli, M. (2020). Auditor's Report, Auditor's Size and Value Relevance of Accounting Information, Journal of Applied Accounting Research. Retrieved from: https://doi.org/10.1016/S2212-5671(15)00109-4

Akeem, L., Rufus, A., Abiodun, S. \& Olawumi, L. (2020). "Audit Reporting Lag and Firm Value in Nigerian Food and Beverage Companies", Market Forces, 15(2): 25-36.

Al-Shatnawi, H. (2017). Measuring the Quality of the Interim Financial Reports using the Qualitative Characteristics of the Accounting Information and its Effect on the Investment Decision according to the IAS 34, International Journal of Accounting and Finance, 9(5): 159170 .

Al-Thuneibat, L., Khamees, L. \& Al-Fayoumi, N. (2008). The Effect of Qualified Auditors' Opinion on Share Prices: Evidence from Jordan, Managerial Auditing Journal, 23(1): 84-101.

Alwardat, Y. (2019). Disclosure Quality and its Impact on Financial Reporting Quality, Audit Quality, and Investors' Perceptions of the Quality of Financial Reporting: A Literature Review. Accounting and Finance Research, 8(3): 201-218.

Bae, C. \& Woo, Y. (2015). The effect of audit report lag and management discretionary report lag on analyst forecasts: evidence from Korea. Investment Management and Financial Innovations, 12(1-2): 318-329.

Bédard, J., Gonthier-Besacier, N., \& Schatt, A. (2014). Costs and benefits of reporting key audit matters in the audit report: The French experience. Retrieved from: https://www.isarhq.org/2014_downloads/papers/ISAR2014_Bedard_ Besacier_Schatt.pdf

Bédard, J., Gonthier-Besacier, N., \& Schatt, A. (2019). Consequences of Expanded Audit Reports: Evidence from the Justifications of 
Assessments in France, Auditing: A Journal of Practice \& Theory, 38(3): 23-35.

Chandrapala, P. (2013). The Value Relevance of Earnings and Book Value: The Importance of Ownership Concentration and Firm Size, Journal of Competitiveness, 5(2): 98-107.

Chen, C., Srinidhi, B. \& Su, X. (2014). Effect of Auditing: Evidence from Variability of Stock Returns and Trading Volume, China Journal of Accounting Research, 7: 223-245.

Christensen, B., Glover, S. \& Wolfe, C. (2014). Do Critical Audit Matter Paragraphs in the Audit Report Change Nonprofessional Investors' Decision to Invest?, Auditing: A Journal of Practice \& Theory, 33(4): 71-93.

Chui, L., Kim, O. \& Pike, B. (2020). The Effect of Audit Duality on Audit Quality, Journal of International Accounting Research, 19(2): 65-89.

DeAngelo, L. (1981). Auditor Size and Audit Quality, Journal of Accounting and Economics, 3: 183-199.

Dye, R. (1993). Auditing Standards, Legal Liability and Auditor Wealth, Journal of Political Economy, 101(5): 884-914.

Elliott, W., Fanning, K. \& Peecher, M. (2020). Do Investors Value Higher Financial Reporting Quality, and Can Expanded Audit Reports Unlock This Value?, The Accounting Review, 95(2): 141-165.

Fakhfakh Sakka, I. \& Jarboui, A. (2016). Audit reports timeliness: Empirical evidence from Tunisia, Cogent Business \& Management, 3, http://dx.doi.org/10.1080/23311975.2016.1195680.

Gaynor, L., Kelton, A., Mercer, M., \& Yohn, T. (2016). Understanding the relation between financial reporting quality and audit quality, Auditing: A Journal of Practice \& Theory, 35(4): 1-22.

Gligorić, M., Mizdraković, L., Mitrašinović, L. \& Marković, V. (2019). Audit Timeliness and Market Capitalization: Evidence from an Emerging Market, Industrija, 47(4): 21-45. 
Gold, A. \& Heilmann, M. (2019). The consequences of disclosing key audit matters (KAMs): A review of the academic literature, Maandblad voor Accountancy en Bedrijfseconomie, 93(1/2): 5-14.

Gold, A., Heilmann, M., Pott, C. \& Rematzki, J. (2020). Do key audit matters impact financial reporting behavior?, International Journal of Auditing, 24: 232-244.

Gould, S. \& Arnold, C. (2020). The Financial Reporting Implications of COVID-19, Accountants Today. Retrieved from: https://www.atmia.my/2020/04/17/the-financial-reporting-implications-of-covid-19/

IAASB. (2018). Conceptual Framework for Financial Reporting, Retrieved from: www.ifrs.org.

IAASB. (2020). Auditor Reporting in the Current Evolving Environment Due to COVID-19, Staff Audit Practice Alert. Retrieved from: http://www.iaasb.org

Ianniello, G. \& Galloppo, G. (2020). Stock market reaction to auditor opinions - Italian evidence, Managerial Auditing Journal, 30(6/7): $610-632$.

ICAEW. (2020). COVID-19: Interim Reporting and the Auditor's Role, Retrieved from: https://www.icaew.com/insights/covid-19-globalrecovery/covid-19-going-concern/audit-reports-and-interimreviews/covid-19-interim-reporting

IFAC. (2015). ISA701, "Communicating Key Audit Matters in the Independent Auditor's Report". Retrieved from: www.ifac.org.

Jonas, G. \& Blanchet, J. (2000). Assessing Quality of Financial Reporting, Accounting Horizons, 14(3): 353-363.

Joshi, P. (2020). COVID-19 Pandemic and Financial Reporting Issues and Challenges, International Journal of Auditing and Accounting Studies, 20(1): 1-9.

Kaplan, S., Taylor, G. \& Williams, D. (2020). The Effects of the Type and Content of Audit Reports for Financially Stressed Initial Public 
Offerings on Information Uncertainty, Auditing: A Journal of Practice \& Theory, 39(1): 125-150.

Kegalj, G. 2020, What is the Impact of COVID-19 on Interim Financial Statements?. Retrieved from: http://assets.kpmg

Khurana, I. \& Raman, K. (2004). Litigation Risk and the Financial Reporting Credibility of Big 4 versus Non-Big 4 Audits: Evidence from Anglo-American Countries, The accounting Review, 79(2): 473495.

Köhler, A., Ratzinger-Sakel, N. \& Theis, J. (2020). The Effects of Key Audit Matters on the Auditor's Report's Communicative Value: Experimental Evidence from Investment Professionals and Nonprofessional Investors, Accounting in Europe. Retrieved from: https://doi.org/10.1080/17449480.2020.1726420

Krishnan, \& Zhang, Y. (2005). Auditor Litigation Risk and Corporate Disclosure of Quarterly Review Report, Auditing: A Journal of Practice \& Theory, 24, Supplement: 115-138.

Lennox, C., Schmidt, J., \& Thompson, A. (2016). Is the expanded model of audit reporting informative to investors? Evidence from the UK, working paper. Retrieved from: https://papers.ssrn.com/sol3/papers.cfm?abstract id=2619785

Li, H. (2017). The Benefit of Adding Key Audit Matters to the Auditing Report, Advances in Economics, Business and Management Research, 49: 21-24.

Lightstone, K., Young, N. \& Mcfadden, T. (2012). Information Quality of Interim Financial Statements, Accounting Perspectives, 11(4): 297313.

Lin, Z., Jiang, Y., Tang, Q. \& He, X. (2014). Does High-Quality Financial Reporting Mitigate the Negative Impact of Global Financial Crises on Firm Performance? Evidence from the United Kingdom, Australasian 
Accounting, Business and Finance Journal, 8(5): 19-46. DOI:10.14453/aabfj. v8i5.3.

Manry, D., Tiras, S. \& Wheatley, C. (2003). The Influence of Interim Auditor Reviews on the Association of Returns with Earnings, The Accounting Review, 78(1): 251-274.

Martínez-Ferrero, J. (2014). Consequences of financial reporting quality on corporate performance. Evidence at the international level, Estudios de Economía, 41(1): 49-88.

Ohlson, J. (1995). Earnings, book values, and dividends in equity valuation, Contemporary Accounting Research, 11(2): 661 - 687.

Okolie, A. \& Izedonmi, F. (2014). The Impact of Audit Quality on the Share Prices of Quoted Companies in Nigeria, Research Journal of Finance and Accounting, 5(8): 150-166.

PwC. (2020). Accounting Implications of the Effects of Coronavirus: PwC in depth INT2020-02, Retrieved from:

https://www.pwccn.com/en/ifrs/acct-implication-coronavirusapr2020.pdf

Robu, M. \& Robu, I. (2015). The influence of the audit report on the relevance of accounting information reported by listed Romanian companies, Procedia Economics and Finance, 20: 562 - 570.

Shrestha, N. (2020). Detecting Multicollinearity in Regression Analysis, American Journal of Applied Mathematics and Statistics, 8(2): 39-42.

Skinner, D. \& Srinivasan, S. (2012). Audit Quality and Auditor Reputation: Evidence from Japan, The Accounting Review, 87(5): 1737- 1765.

Sulaiman, O. \& Ahmad, A. (2016). The Impact of Reviewing Interim Financial Reports on the Investors Decisions in Kurdistan Region, International Journal of Scientific \& Technology Research, 5(12): 221-225. 
Sutthipan, M. (2020). KAM Reporting and Common Share Price of Listed Companies in The Market of Alternative Investment from Thailand, Academy of Accounting and Financial Studies Journal, 24(3). Retrieved from: https://www.abacademies.org/articles/kam-reportingand-common-share-price-of-listed-companies-in-the-market-ofalternative-investment-from-thailand-9295.html

Tasios, S. \& Bekiaris, M. (2012). Auditor's perceptions of financial reporting quality: the case of Greece, International Journal of Accounting and Financial Reporting, 2(1): 57-73.

Velte, P. \& Issa, J. (2019). The Impact of Key Audit Matter (KAM) Disclosure in Audit Reports on Stakeholders' Reactions: A Literature Review, Problems and Perspectives in Management, 17(3): 323-341.

Zeng, Y., Zhang, J., Zhang, J. \& Zhang, M. (2020). Key Audit Matters Reports in China: Their Descriptions and Implications of Audit Quality, Accounting Horizons, DOI: https://doi.org/10.2308/HORIZONS-19-189 
Vol.2, No.2, Part 1., July 2021

Dr. Hebatallah Badawy

\section{أثر جودة وفورية تقرير الفحص المحدود على الجودة المدركة للتقارير المالية المرحلية خلال أزمة جائحة كورونا: دليل من مصرد الجرد المدرك}

إعداد

$$
\text { كلد أستاذ المحاسبة والله عبد السلام بلدوي التجارة التعة المساعد }
$$

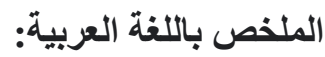

يجب أن تتصف المعلومات المالية بالملاءمة و التمثيل العادل حتى يمكن استخدامها

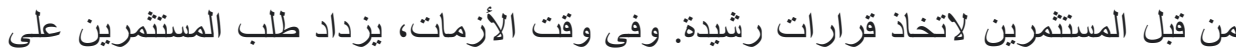

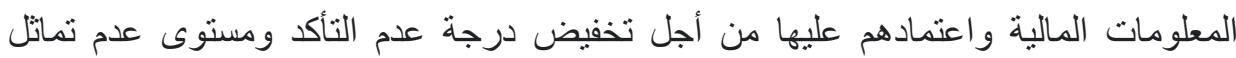

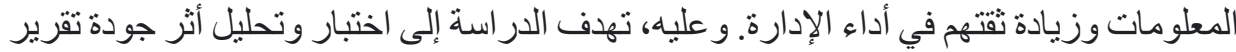

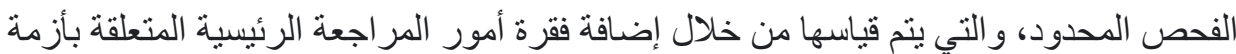

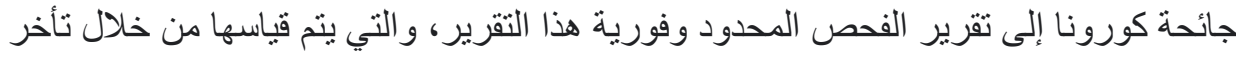

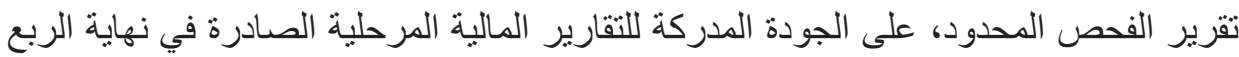

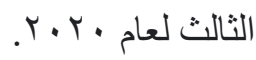

بناء على عينة من 90 شركة مدرجة في بورصة الأوراق المالية المصرية، توصل الباحث إلى وجود علاقة إيجابية وجوهرية بين فورية تقارير الفحص المحدود و الجودة المدركة

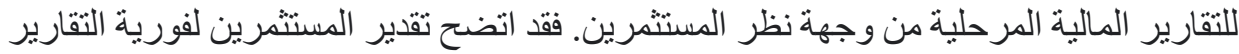

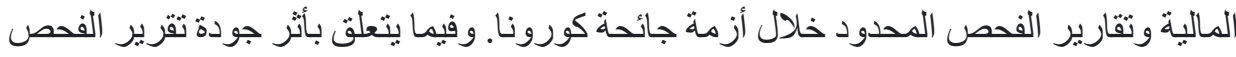

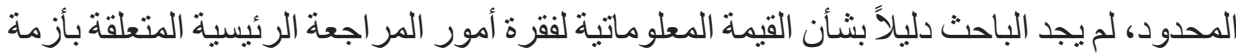

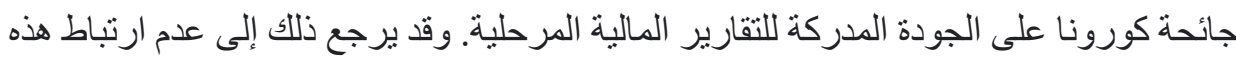

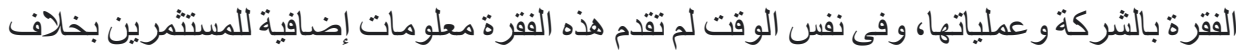
تلاك المتوفرة في التقارير المالية المرحلية.

الكلمات المفتاحية

جودة تقرير الفحص المحدود، التقارير المالية المرحلية، تأخر تقرير الفحص المحدود، أزمة جائحة كورونا، مصر. 